\title{
Managing Fire in the Northern Chihuahuan Desert: A Review and Analysis of the Literature
}

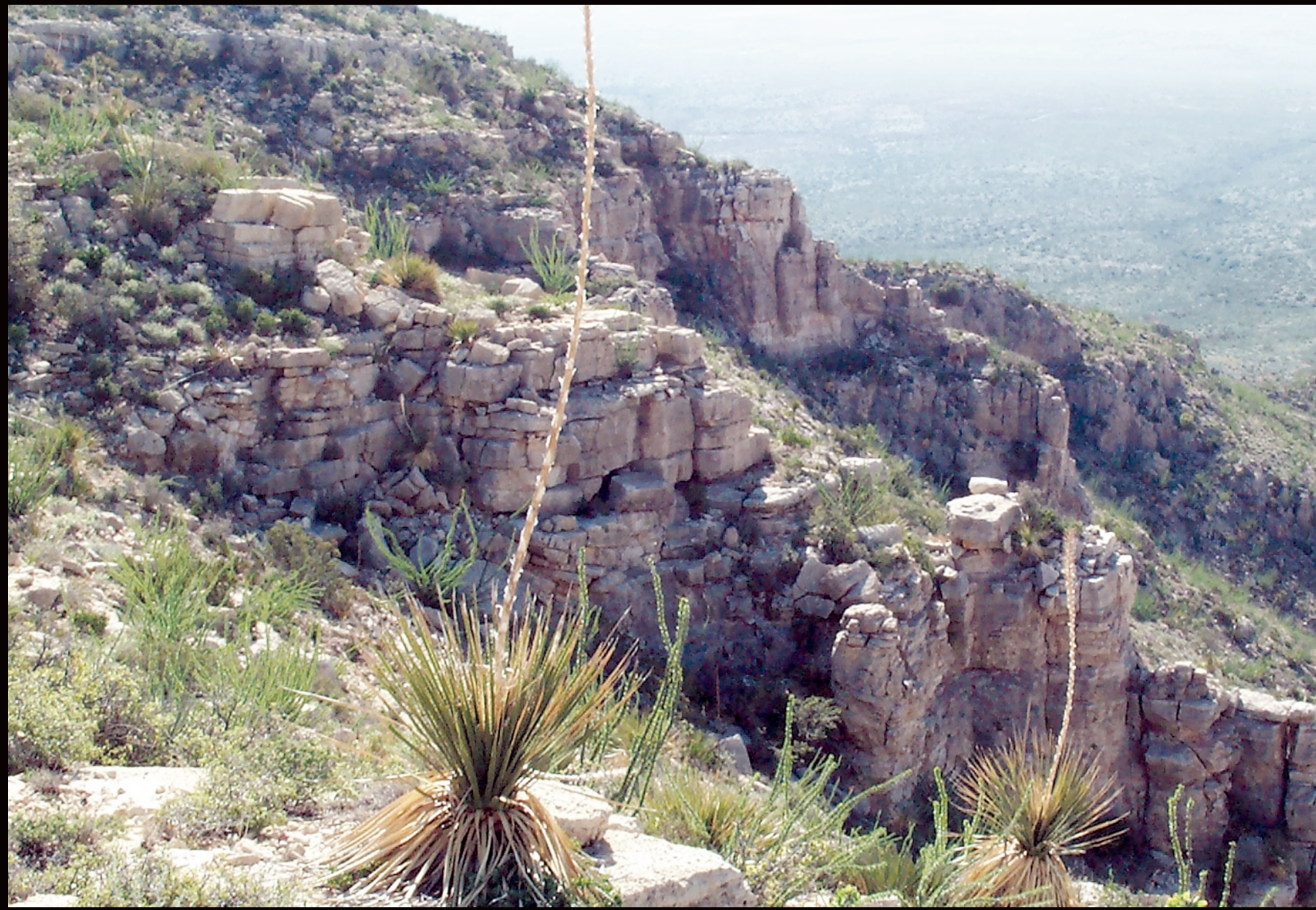

Southwest Biological Science Center

Open-File Report 2005-1157

April 2005

U.S. Department of the Interior

U.S. Geological Survey 



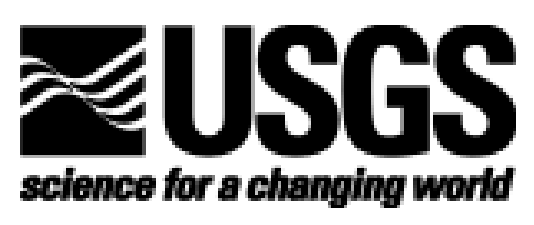

In cooperation with the National Park Service and the University of Arizona School of Natural Resources

\section{Managing Fire in the Northern Chihuahuan Desert: A Review and Analysis of the Literature}

By Brooke S. Gebow and William L. Halvorson

Open-File Report 2005-1157

April 2005

U.S. Department of the Interior

U.S. Geological Survey 


\section{U.S. Department of the Interior \\ Gale A. Norton, Secretary}

\section{U.S. Geological Survey \\ Charles G. Groat, Director}

U.S. Geological Survey, Reston, Virginia: 2005

Suggested Citation

Gebow, B. S., and W. L Halvoson. 2004. Managing Fire in the Northern Chihuahuan Desert: A

Review and Analysis of the Literature. USGS Open-File Report SBSC-SDRS-2004-1001. U.S. Geological Survey, Southwest Biological Science Center, Sonoran Desert Research Station, University of Arizona, Tucson, AZ.

Cover photo: Dale Pate, Carlsbad Caverns National Park 


\section{Authors}

Brooke S. Gebow

School of Renewable Natural Resources

125 Biological Sciences East

The University of Arizona

Tucson, Arizona 85721

William L. Halvorson

USGS Sonoran Desert Research Station

125 Biological Sciences East

The University of Arizona

Tucson, Arizona 85721

\section{U.S. Geological Survey Station Personnel}

Charles van Riper, III, Station Leader

William L. Halvorson, Research Ecologist

Cecil R. Schwalbe, Ecologist

Michael R. Kunzmann, Ecologist

Ana Luisa Moore, Administrative Assistant

\section{Program and Expertise Areas of USGS and UA Personnel}

Administration \& Outreach

Kathleen Docherty

Cori Dolan

Brooke Gebow

Bill Halvorson

Ana Luisa Moore

Charles van Riper, III

Avian Ecology

Mike Kunzmann

Chris O'Brien

Brian Powell

Charles van Riper, III

Data Management

Mike Kunzmann

Brent Sigafus

Ecology of Amphibians \& Reptiles

Kevin Baker

Cristina Jones

Phil Rosen

Cecil Schwalbe

Brent Sigafus

Dennis Suhre
Fire Management

Cori Dolan

James Feldmann

Brooke Gebow

Susan Moodie

Invasive Species Research

Patricia Guertin

Jim Malusa

Phil Rosen

Cecil Schwalbe

Brent Sigafus

Dennis Suhre

Inventory \& Monitoring

Kathleen Docherty

Patricia Guertin

Bill Halvorson

Brian Powell

Cecilia Schmidt

Vegetation Mapping \& Ecology

Patricia Guertin

Bill Halvorson

Jim Malusa 


\section{Table of Contents}

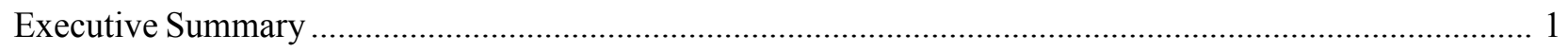

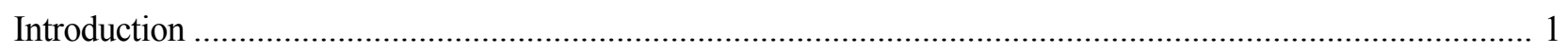

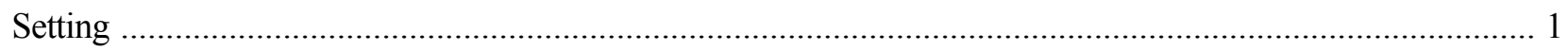

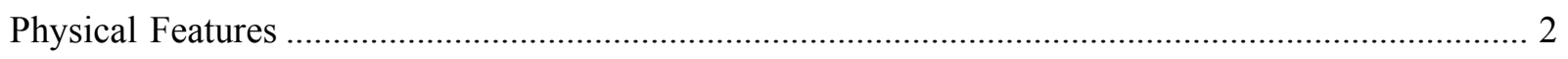

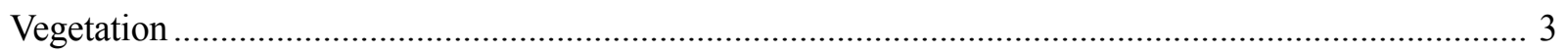

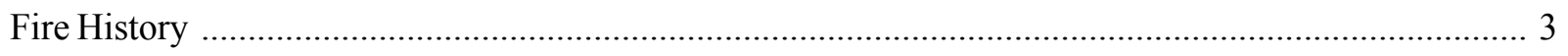

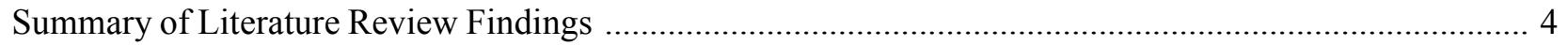

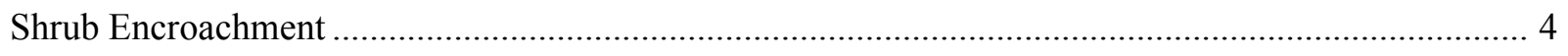

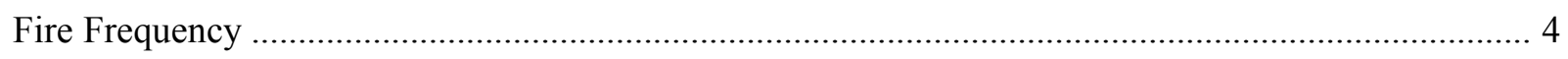

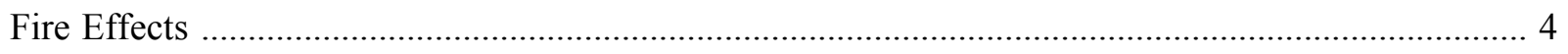

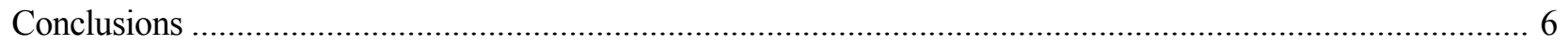

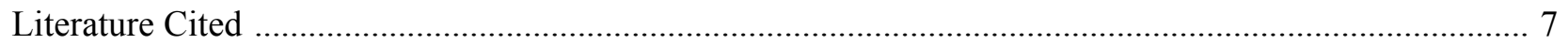

Appendix 1. Reviews of papers, reports, and book chapters relevant to fire

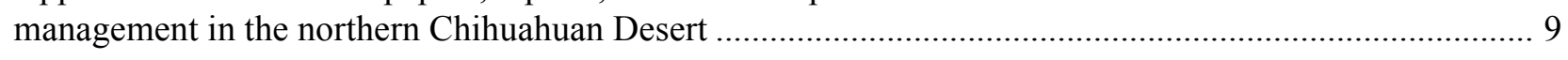

Appendix 2. Summary of fire effects on Gelbach's (1967) leading dominant plant ................................. 33 species of the Guadalupe Escarpment 


\section{List of Tables}

Table 1. Monthly Climate Summary for Carlsbad Caverns, New Mexico, 1930-2000 …........................... 2

Table 2. Carlsbad Caverns plant communities from 1995 Fire Management Plan ................................... 3

Table 3. Guadalupe Escarpment leading dominant plant species ............................................................. 3

Table 4. Carlsbad Caverns National Park fire history data .................................................................. 4

Table 5. Summary of fire interval information from the literature ............................................................. 5

\section{List of Figures}

Figure 1. Northern Chihuahuan Desert and location of Carlsbad Caverns .............................................. 2

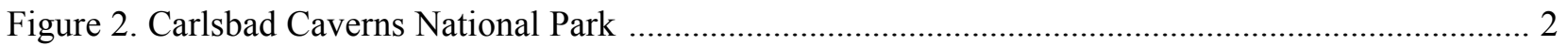

\section{Acknowledgements}

The two projects on which this report is based were funded by the National Park Service. Previous literature analysis was supported through an NPS Intermountain Region cooperative agreement with the University of Arizona. Fire history work was facilitated by the NPS Desert Southwest Cooperative Ecosystems Studies Unit under the guidance of Larry Norris. Diane Dobos-Bubno, David Roemer, Tim Stubbs, and Renée West at Carlsbad Caverns National Park gathered together much of the literature for the review, and David and Renée took the time to review and add improvements to this manuscript. Fire ecologists Kathy Davis (National Park Service Southern Arizona Office) and Malcolm Zwolinski (University of Arizona School of Natural Resources) also served as reviewers and made many helpful suggestions. We are grateful for the assistance of all. 


\section{Managing Fire in the Northern Chihuahuan Desert: A Review and Analysis of the Literature}

\section{Executive Summary}

This report began as a literature review (Gebow and Halvorson 2001) conducted for fire planners at Carlsbad Caverns National Park who were seeking information about (1) the natural state of park vegetation, (2) northern Chihuahuan Desert natural fire regimes, and (3) fire effects on park plant species. It is the goal of managers there to continue to refine the wildland and prescribed fire program as they learn more about the ecosystems at the park. The park has a history of grazing and then fire suppression in the $20^{\text {th }}$ century. The current effort revisits questions asked by earlier workers at the park, Walter Kittams and Gary Ahlstrand, who began fire studies in the 1970s.

This document addresses ecosystems and historical change to those systems in Chihuahuan Desert areas of southeast Arizona, southern New Mexico, west Texas, or in neighboring regions that share the same plant species. It examines fire literature for situations possibly analogous to those at Carlsbad Caverns. It also includes papers that offer advice on extrapolating future ecological trends from past ones (Swetnam et al. 1999) and on resource management decision-making (Grumbine 1997), and other pieces that address broader aspects of fire or landscape change (Goldman 1994; Marston 1996; Mutch 1994, 1995). These more philosophical works were included in the original review at the park's request and have been retained here because they discuss other issues relevant to fire management.

Individual reviews of 35 papers, as requested originally by Carlsbad Caverns, appear in Appendix 1. The results section - summary of key findings - discusses historical changes to plant communities then focuses on burn intervals observed or recommended by workers for particular plant communities. Results from a search of the USDA Forest Service's Fire Effects Information System (www.fs.fed.us/database/feis) are also included in this report, supplemented with information from a review conducted by Ahlstrand (1981b) that included much of his own work. This database contains comprehensive plant species accounts and fire effects data. Entries are available for a number of the dominant species at Carlsbad Caverns, though the information frequently applies to the plants in other parts of their ranges.

The literature presents highly variable fire effects and observed/recommended burn intervals for similar plant communities in the northern Chihuahuan Desert region. While local and longer-term fire-effects studies are still needed to guide resource managers, the variability seen in the literature itself translates into a fire management goal. Preserving the irregularity in time and space of fires would likely best replicate "natural" fire regimes.

\section{Introduction}

In a national park, fire needs to be managed in a way that maintains its role in ecosystems but keeps people and irreplaceable resources safe. Accomplishing the first goal requires information that may not be available. In order to allow fire to serve in its natural ecological capacity, both the natural state of the ecosystem and the role of fire in that system need to be known. In the National Park Service, the Leopold report (Leopold et al. 1963) guides policy in this area, stating, "As a primary goal, we would recommend that the biotic associations within each park be maintained, or where necessary recreated, as nearly as possible in the condition that prevailed when the area was first visited by white man." While historical accounts provide no detailed descriptions of pre-Anglo plant communities in the area addressed by this report, we can be certain that grazing and fire suppression, mostly during the $20^{\text {th }}$ century, have altered the landscape, likely in predictable ways.

The work of two Carlsbad Caverns ecologists in the 1970s is often cited in descriptions of Chihuahuan Desert fire regimes. Walter Kittams (1972) qualitatively described burn sites within six months of, then three years after, 10 natural fires at the park. Gary Ahlstrand (1982) set up plots in areas that were unburned, three years postburn, and six or seven years post burn and made one reading of cover by growth form on all the plots. The studies were not continued after these staff members went elsewhere.

This report is an attempt to build on the foundation constructed by Kittams and Ahlstrand. It first describes the Carlsbad Caverns area, plant communities targeted by the literature review, and park fire history. We then summarize the fire literature findings and include detailed individual reviews in Appendix 1. A compilation of fire effects data covers a number of dominant species at the park. Finally we make some conclusions about how the results of the literature review might be applied to fire management planning in the region.

\section{Setting}

Carlsbad Caverns National Park sits at the edge of the Chihuahuan Desert on the eastern end of the Guadalupe Mountains in Eddy County, New Mexico, just north of the 


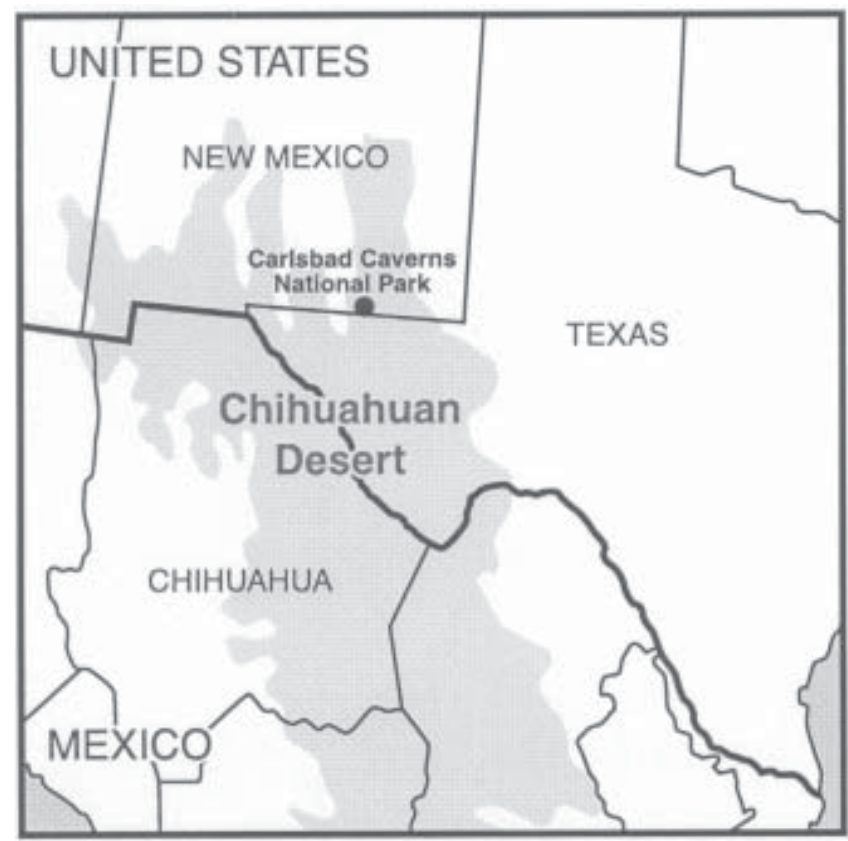

Figure 1. Northern Chihuahuan Desert and location of Carlsbad Caverns.

Texas state line (Figure 1). The desert reaches its northeastern limit in southeastern New Mexico and is replaced by the Great Plains to the east and Rocky Mountain region to the north.

\section{Physical Features}

The Guadalupe Mountains are a remnant of a Permian reef that ringed a sea in what is now the Delaware Basin, mostly to the south and east. Geologists assign the Guadalupes to Trans-Pecos Texas, a mixed-age, mixedorigin basin-and-range complex that is part of the petroleum- and gas-rich Permian Basin west of the Pecos River (Brand and Jacka 1979).

The southern edge of Carlsbad Caverns is defined by the Guadalupe Escarpment that runs the park's 21-mile length
(Figure 2). Elevation at the base of the escarpment near the park entrance is $1100 \mathrm{~m}$ above sea level. Elevation at the top increases from east to west, reaching $1950 \mathrm{~m}$ in the highlands at the western edge and declining to $1200 \mathrm{~m}$ at the east end. Elevation at the visitors center is about 1340 $\mathrm{m}$

Table 1 summarizes weather data collected near the visitors center between 1930 and 2000. Rain falls primarily between May and October, with an annual average of $380 \mathrm{~mm}$. Winters are mild and summers hot, with January's $0.9^{\circ} \mathrm{C}$ the lowest monthly minmum temperature, and July's $33.0^{\circ} \mathrm{C}$ the highest monthly maximum (Western Regional Climate Center 2001). The fire season at Carlsbad Caverns corresponds with the summer rainy season, when lightning and wind start and spread fires, respectively; natural ignitions peak in June and July (Gebow and Halvorson 2002).

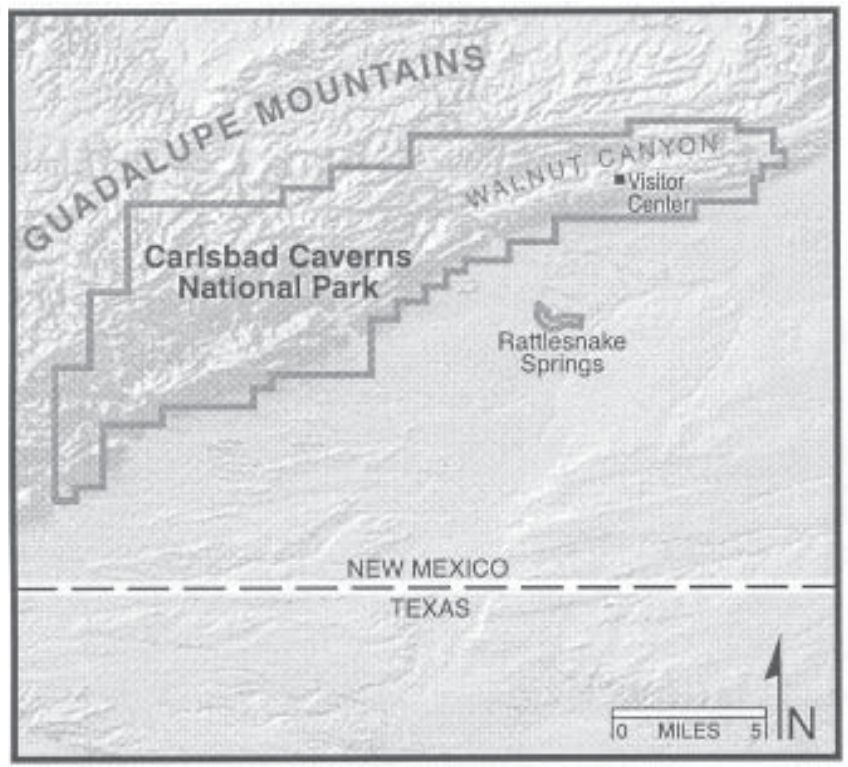

Figure 2. Carlsbad Caverns National Park.

Table 1. Monthly Climate Summary for Carlsbad Caverns, New Mexico, 1930-2000 (Western Regional Climate Center 2001).

Jan Feb Mar Apr May Jun Jul Aug Sep Oct Nov Dec Annual

$\begin{array}{llllllllllllll}\text { Average Max } & 13.6 & 16.0 & 19.5 & 24.6 & 28.7 & 32.8 & 33.0 & 31.9 & 28.7 & 24.0 & 18.2 & 14.4 & 23.7 \\ \text { Temperature }\left({ }^{\circ} \mathrm{C}\right) & 13.6 & & & & & & & & & & & & \end{array}$

$\begin{array}{llllllllllllll}\text { Average Min } & 0.9 & 2.6 & 5.4 & 9.8 & 14.4 & 18.1 & 19.2 & 18.8 & 15.8 & 11.3 & 5.4 & 1.8 & 15.9 \\ \text { Temperature }\left({ }^{\circ} \mathrm{C}\right) & & & & & & & & & & & \end{array}$
Average Total Precipitation (mm)
$\begin{array}{lll}12.4 & 10.9 & 9.1\end{array}$
$15.7 \quad 37.1$
$46.5 \quad 50.3$
60.2
$\begin{array}{llll}75.4 & 36.1 & 11.9 & 13.0\end{array}$
378.7 
Table 2. Carlsbad Caverns plant communities from 1995 Fire Management Plan.

Low elevation: desert shrub (12,500 ha)

Acacia constricta (white-thorn acacia)

Agave lechuguilla (lechuguilla)

Bouteloua spp. (grama grasses)

Dasylirion leiophyllum (sotol)

Flourensia cernua (tarbush)

Fouquieria splendens (ocotillo)

Juniperus pinchotii (red-berry juniper)

Larrea tridentata (creosote bush)

Mimosa biuncifera (catclaw mimosa)

Muhlenbergia spp. (muhly grasses)

Opuntia spp. (prickly pear)

Tridens muticus (slim tridens)

Mid elevation: grassland-shrub (6000 ha)

Agave lechuguilla (lechuguilla)

Agave neomexicana (New Mexico agave)

Aristida spp. (three-awn grasses)

Ceanothus greggii (ceanothus)

Cercocarpus montanus (mountain mahogany)

Dasylirion leiophyllum (sotol)

Eragrostis spp. (lovegrasses)

Mimosa biuncifera (catclaw mimosa)

Muhlenbergia spp. (muhly grasses)

Nolina micrantha (sacahuista)

Quercus spp. (oaks)

Viguiera stenoloba (golden-eye)

High elevation: juniper woodland (600 ha)

Juniperus deppeana (alligator juniper)

Pinus ponderosa (Ponderosa pine)

Pseudotsuga menziesii (Douglas-fir)

\section{Vegetation}

The 1995 Fire Management Plan for Carlsbad Caverns outlines a simple scheme, characterized by the species in Table 2.

Gelbach (1967) examined the vegetation of the Guadalupe Escarpment and identified leading dominants using a physiognomic approach that weighted species' presence in vertical strata. He sorted dominants according to their relative "xerophytic adaptation" and came up with groupings of leading dominants for different sites.

Gelbach's leading dominants across all sites are listed in Table 3 in order of descending importance.

Gelbach sorts dominants into four formation types. At the base of the escarpment are two slightly different shrub desert formations; Larrea-Flourensia occupies somewhat
Table 3. Guadalupe Escarpment leading dominant plant species from Gelbach (1967). Dominance order begins with the left-hand column. Correspondence among botanists in park files from 1969 indicates agreement that $J$. pinchotti ( ${ }^{*}$ below) should replace $J$. monosperma originally on Gelbach's list.

Agave lechuguilla
Quercus grisea
Juniperus pinchotii*
Dasylirion leiophyllum
Larrea tridentata
Acacia constricta
Mimosa biuncifera
Juniperus deppeana
Tridens muticus
Gutierrezia lucida
G. sarothrae
Rhus trilobata
Opuntia imbricata
Viguiera stenoloba
Muhlenbergia setifolia

Juniperus pinchotii*

Dasylirion leiophyllum

Acacia constricta

Mimosa biuncifera

Juniperus deppeana

Tridens muticus

Gutierrezia lucida

G. sarothrae

Rhus trilobata

gia setifolia
Agave lechuguilla
B. hirsuta
B. curtipendula
Juglans microcarpa
Acer grandidentatum
Nolina microcarpa
Lesquerella fendlerii
Fallugia paradoxa
Brickellia laciniata
Aristida glauca
Parthenium incanum
Flourensia cernua
Opuntia phaecantha
O. englemannii
Bouteloua eriopoda

drier sites than Acacia-Larrea. Dasylirion-Agave and the grassier Juniperus-Agave succulent desert formations are found on escarpment slopes; the former occurs in bouldery areas. Gelbach assigns three dominance types to the evergreen woodland formation, Quercus [grisea]Juniperus [pinchotii] in canyons and on gravelly loams above $1370 \mathrm{~m}$, Quercus-Juniperus [deppeana] only in protected canyons, and Juniperus-Pinus [edulis] above 2400 m. An unusual Juglans-Dasylirion deciduous woodland formation pairs mesophytic Juglans with xerophytic Dasylirion along ephemeral streams.

\section{Fire History}

Walter Kittams and Gary Ahlstrand studied fire at Carlsbad Caverns during the 1970s and early 1980s when fire was making a comeback in the park. Table 4 shows that fire numbers and area burned both rose as the fire suppression era came to a close and fuel levels increased when grazing ceased (Gebow and Halvorson 2002). Human-caused fires were more common in the early decades represented in Table 4, and lightning ignitions outnumber other causes in later years. Most fires are very small; increases in area burned over time are mainly a function of occasional large fires rather than an increase in the size of all fires (Gebow and Halvorson 2002). Currently fires are managed as prescribed natural fires in the "natural zone," conditionally suppressed or burned according to prescription in the "conditional suppression zone," or fully suppressed as dictated by the 1995 Fire Management Plan. Most of the park falls in the natural 
Table 4. Carlsbad Caverns National Park fire history data (Gebow and Halvorson 2002).

\begin{tabular}{|c|c|c|}
\hline Tim e P erio d & $\begin{array}{l}\mathrm{Number} \\
\text { of } \mathrm{F} \text { ires }\end{array}$ & $\begin{array}{r}\text { Hectares } \\
\text { Burned }\end{array}$ \\
\hline $1941-1945$ & 17 & 109 \\
\hline $1946-1950$ & 12 & 11 \\
\hline $1951-1955$ & 16 & 77 \\
\hline $1956-1960$ & 4 & 30 \\
\hline $1961-1965$ & 6 & 15 \\
\hline $1966-1970$ & 15 & 75 \\
\hline $1971-1975$ & 13 & 6676 \\
\hline $1976-1980$ & 38 & 394 \\
\hline $1981-1985$ & 44 & 1357 \\
\hline $1986-1990$ & 36 & 16,203 \\
\hline $1991-1995$ & 61 & 2186 \\
\hline $1996-2000$ & 20 & 1164 \\
\hline
\end{tabular}

zone, with suppression important around developed areas, park boundaries, and Rattlesnake Springs, a wetland south of the escarpment that is not contiguous with the rest of the park.

\section{Summary of Literature Review Findings}

Appendix 1 contains individual reviews of 35 papers, reports, or book chapters that shed light on the plant communities, fire, and fire management in the northern Chihuahuan Desert region. We discuss prominent themes from the literature below.

\section{Shrub Encroachment}

The Chihuahuan Desert landscape that encompasses Carlsbad Caverns National Park has not been static over the period of prehistoric and historical record. Looking back over the last 10,000 years, ranchers have grazed livestock, Indians may have set fires, prehistoric humans reduced numbers of large mammals, climate changes rearranged plant distributions, and geologic events rerouted water (Ahlstrand 1981a; Gelbach 1981). Throughout much of the northern Chihuahuan Desert a recent shift from grasses to shrubs has taken place (Buffington and Herbel 1965; York and Dick-Peddie 1969; Grover and Musick 1990). Explanations for the change incorporate three main agents: (1) grazing, (2) fire suppression, and (3) a drying trend. Many workers favor grazing as the strongest factor (Buffington and Herbel 1965; Ahlstrand 1981a; Dick-Peddie 1993), although Humphrey (1974) gives fire suppression and grazing equal weight.

Around Carlsbad the grazing hypothesis fits; at lower elevations grazing in the $20^{\text {th }}$ century altered the soil conditions that favor grasses and removed fine fuels that carry fire and help check shrubs (Ahlstrand 1982). At higher elevations, grazing removed grasses that compete for moisture with juniper seedlings, and junipers expanded into new habitats. Ahlstrand (1981a) reported a significant decrease in 10-year moving rainfall average from before 1900 through 1970 for Carlsbad, NM, El Paso, TX, and Las Cruces, NM, that would also promote shrubs over grasses.

There is no clear definition of the pre-Anglo condition at Carlsbad Caverns, but "grassier" likely represents a pregrazing, pre-fire-suppression scenario. The Pope expedition scribes (Pope 1855) repeatedly gave rave reviews to the grass around the Guadalupe Mountains; these men were surveying for a railroad route and were accompanied by abundant livestock that needed nightly forage. Ahlstrand (1981a) suggested that species composition had not changed in the Guadalupes so much as densities.

\section{Fire Frequency}

Fire managers are particularly looking for guidance about how often landscapes should burn. Table 5 summarizes fire interval information from the reviewed papers. The shortest intervals and those based on tree ring studies come from actual data, but most of the numbers in Table 5 are estimates or suggestions. Ahlstrand's (1982) observation that burn boundaries were indistinguishable 6-7 years post-fire suggests a lower end burn interval for management purposes in the "mountain shrub" community.

Kaib et al. (1996) deduce four- to nine-year fire intervals for semidesert grassland in southeastern Arizona. Their conclusion is based on the assumption that synchronous fires (documented by tree rings) in separated mountain canyons spread via grasslands rather than within the mountain range.

\section{Fire Effects}

Appendix 2 presents brief accounts of fire effects for Carlsbad Caverns plant species. Very generally, grasses recover from fire within a few years, but are not necessarily enhanced by it and do poorly when burning coincides with or precedes drier than normal conditions. Most mature trees and shrubs are able to resprout after fire, but can be harmed by repeated burning. Succulents fare poorly, but less so when moisture levels are high. The 
Table 5. Summary of fire interval information from the literature. CAVE refers to Carlsbad Caverns National Park.

\begin{tabular}{|c|c|c|c|}
\hline $\begin{array}{l}\text { Number } \\
\text { of years }\end{array}$ & Description & Location & Source \\
\hline 1 & $\begin{array}{l}\text { \# years after fire when } 30-60 \% \text { cactus kill observed in semidesert } \\
\text { grassland, in one study }\end{array}$ & $\begin{array}{l}\text { Santa Rita Exp } \\
\text { Range, SE AZ }\end{array}$ & Cable 1973 \\
\hline 1 & $\begin{array}{l}\text { \# years after fire when no change in cactus densities observed in } \\
\text { semidesert grassland, in another study }\end{array}$ & $\begin{array}{l}\text { Santa Rita Exp } \\
\text { Range, SE AZ }\end{array}$ & Cable 1973 \\
\hline 2 & $\begin{array}{l}\text { \# years after fire when burned big sacaton recovered to pretreatment } \\
\text { levels }\end{array}$ & $\begin{array}{l}\text { Santa Rita Exp } \\
\text { Range, SE AZ }\end{array}$ & Cox 1988 \\
\hline 3 & $\begin{array}{l}\text { \# years after fire when coverage on control plots still exceeded burn } \\
\text { plot coverage for grasses, forbs, woody shrubs, and succulents }\end{array}$ & CAVE & Ahlstrand 1982 \\
\hline 4.7 & $\begin{array}{l}\text { mean \# years between fires in the Guadalupe Mountains high country } \\
1554-1842\end{array}$ & Guadalupes & Ahlstrand 1981c \\
\hline 5 & $\begin{array}{l}\text { \# years after fire estimated for tobosagrass coverage on burned plots } \\
\text { to equal control plots }\end{array}$ & Rolling Plains of TX & $\begin{array}{l}\text { Neuenschwander et } \\
\text { al. } 1978\end{array}$ \\
\hline $5-10$ & $\begin{array}{l}\text { estimated \# years between fires in s. Great Plains to keep shrubs at } \\
\text { bay }\end{array}$ & $\mathrm{TX}$ & Wright 1990 \\
\hline 6 & $\begin{array}{l}\text { \# years of post-fire observations of mesquite, lotebush (Ziziphus } \\
\text { obtusifolia), and prickly pear after which burn plot shrubs had still } \\
\text { not recovered to control plot size }\end{array}$ & Rolling Plains of TX & $\begin{array}{l}\text { Neuenschwander et } \\
\text { al. } 1978\end{array}$ \\
\hline $6-7$ & $\begin{array}{l}\text { \# years after fire when coverage on burned plots exceeded controls } \\
\text { for grasses, forbs and woody shrubs }\end{array}$ & CAVE & Ahlstrand 1982 \\
\hline $6-7$ & $\begin{array}{l}\text { \# years after fire when coverage on control plots still exceeded burns } \\
\text { for succulents }\end{array}$ & CAVE & Ahlstrand 1982 \\
\hline 6-8 & $\begin{array}{l}\text { \# years after fire when black grama estimated to return to preburn } \\
\text { levels in semidesert grassland }\end{array}$ & $\begin{array}{l}\text { Jornada } \\
\text { Experimental Range, } \\
\text { NM }\end{array}$ & Cornelius 1988 \\
\hline 7 & $\begin{array}{l}\text { \# years after fire when fire boundaries were indistinguishable in } \\
\text { montane shrub community }\end{array}$ & CAVE & Ahlstrand 1982 \\
\hline $4-9$ & $\begin{array}{l}\text { estimate of semidesert grassland fire frequency, based on intercanyon } \\
\text { and individual canyon fire frequencies derived from tree-ring data } \\
\text { from pine-oak woodlands }\end{array}$ & $\begin{array}{l}\text { Chiricahua } \\
\text { Mountains, AZ }\end{array}$ & Kaib et al. 1996 \\
\hline $10-15$ & $\begin{array}{l}\text { \# years between burns suggested for increasing grass cover, } \\
\text { decreasing shrub cover }\end{array}$ & CAVE & Ahlstrand 1982 \\
\hline 10 & $\begin{array}{l}\text { \# years between fires suggested to maintain "grassland aspect" on } \\
\text { grass-favorable sites }\end{array}$ & CAVE & Kittams 1972 \\
\hline
\end{tabular}


Table 5, continued. Summary of fire interval information from the literature.

\begin{tabular}{|c|c|c|c|}
\hline $\begin{array}{l}\text { Number } \\
\text { of years }\end{array}$ & Description & Location & Source \\
\hline $10-30$ & $\begin{array}{l}\text { estimated \# years between fires required required to restrict } \\
\text { junipers to rocky, shallow, rough places }\end{array}$ & Southwest & Wright 1990 \\
\hline 17.4 & $\begin{array}{l}\text { mean \# years between major fires in the Guadalupes 1696- } \\
1922\end{array}$ & $\begin{array}{l}\text { Guadalupe } \\
\text { Mountains }\end{array}$ & Ahlstrand 1981c \\
\hline $20-30$ & $\begin{array}{l}\text { minimum \# years between fires in Arizona chaparral } \\
\text { estimated to maximize species diversity }\end{array}$ & Arizona & Wright 1990 \\
\hline $20-40$ & $\begin{array}{l}\text { recommended \# years between fires to maintain pinyon- } \\
\text { juniper stands converted to grassland }\end{array}$ & Southwest & Wright 1990 \\
\hline $25-30$ & $\begin{array}{l}\text { \# years estimated for junipers to recover full canopy spread } \\
\text { after fire }\end{array}$ & CAVE & Kittams 1972 \\
\hline 30 & $\begin{array}{l}\text { maximum \# years between major fires in the Guadalupes } \\
\text { before the } 20 \text { th century }\end{array}$ & $\begin{array}{l}\text { Guadalupe } \\
\text { Mountains }\end{array}$ & Ahlstrand 1981b \\
\hline $50-100$ & $\begin{array}{l}\text { estimated \# years between fires in oak brush habitats under } \\
\text { natural conditions }\end{array}$ & Southwest & Wright 1990 \\
\hline 70 & $\begin{array}{l}\text { \# years between scar-producing fires in woodland at } 2600 \\
\mathrm{~m} \mathrm{w} \text { ith no difference in interval before or after } 1880 \mathrm{~s}\end{array}$ & $\begin{array}{l}\text { Chisos Mtns, Big } \\
\text { Bend, TX }\end{array}$ & Moir 1982 \\
\hline
\end{tabular}

fire effects literature states for many of these species that fire is not common in their habitats due to lack of fuel to carry it.

\section{Conclusions}

One of the original goals of the work presented in this report was to find information about fire frequency in the plant communities present in Carlsbad Caverns National Park. While the mean interval between fires might be a tidy descriptor, such a statistic is only one of many factors fire managers must consider. The rules that govern the natural fire regime in places like the northern Chihuahuan Desert are complex. Stephen Pyne (1984) in the preface to Introduction to Wildland Fire sums up the problems inherent in generalizing about fire: "Because it integrates so many probabilistic processes and because not all of its important relationships are known, wildland fire remains a largely local and particularized phenomenon."

The literature and the patchy distribution of vegetation over rocky slopes and meandering canyon bottoms offer a sense that fire is a natural part of the Carlsbad Caverns landscape but regular fire is not. In this place where the climate is dry and rainfall unpredictable from year to year, the park's prescribed fire program sometimes has problems getting vegetation to burn. "Mixed" fire regime, a term that is assigned to some ponderosa pine forests (Brown and Smith 2000), may apply for this system. It implies a mixture of fire intervals and severities over the history of the landscape; such a regime might be maintained by complex topography and vegetation mosaics.

The park's 1995 Fire Management Plan states that a goal of the prescribed burn program is to use fire to "reestablish and maintain natural vegetation communities..." Fuel reduction for protection of life and property becomes a major objective for most burns rather than achieving particular species composition or relative coverages. However, if the fire program targets areas that have not burned for a long time, burns will likely knock back fireintolerant species. Over the long term, depending on fire frequency and moisture conditions, vegetation dominance may swing back and forth between quick-growing grasses, and succulents and shrubs that take longer to resprout or 
reseed. Barton (1999) describes such a shifting dynamic for pine-oak woodlands - thick-barked pines dominate with frequent fires that top-kill oaks, and oaks increase with infrequent fires.

Whether a fire management program at Carlsbad Caverns can continue moving park vegetation towards a pre-Anglo state is difficult to determine. Rocky landscapes throughout the topographically variable national park do not have the appearance of being irreversibly altered by grazing, which may have led Ahlstrand (1981a) to conclude that abundances rather than species composition had shifted. The fire effects monitoring program mandated by the National Park Service theoretically allows assessment of vegetation coverage and composition; because effects are highly variable in early post-fire years, it takes persistence and a lot of data to see significant patterns.

Preserving the irregularity in time and space of fires would likely best replicate "natural" fire regimes. By moving around the park and burning patches with high fuel loads when conditions permit, the fire program may be mimicking lightning ignitions that result in mainly small fires.

\section{Literature Cited}

Ahlstrand, G. M. 1981a. Ecological role of fire in the Guadalupe Mountains region. P. 102-125 in G. M. Ahlstrand, principal investigator. Ecology of fire in the Guadalupe Mountains and adjacent Chihuahuan Desert. Carlsbad Caverns and Guadalupe Mountains National Parks, Carlsbad, NM.

Ahlstrand, G. M. 1981b. The effects of fire on some plants native to Guadalupe Mountains and Carlsbad Caverns National Parks. P. 35-61 in G. M. Ahlstrand, principal investigator. Ecology of fire in the Guadalupe Mountains and adjacent Chihuahuan Desert. Carlsbad Caverns and Guadalupe Mountains National Parks, Carlsbad, NM.

Ahlstrand, G. M. 1981c. High country fire history. P. 1-22 in G. M. Ahlstrand, principal investigator. Ecology of fire in the Guadalupe Mountains and adjacent Chihuahuan Desert. Carlsbad Caverns and Guadalupe Mountains National Parks, Carlsbad, NM.

Ahlstrand, G. M. 1982. Response of Chihuahuan Desert mountain shrub vegetation to burning. J. Range Management 35:62-65.

Barton, A. M. 1999. Pines versus oaks: effects of fire on the composition of Madrean forests in Arizona. Forest Ecology and Management 120:143-156.
Brand, J. P., and A. D. Jacka. 1979. Geology of the Guadalupe Mountains National Park. P. 1-11 in H. H. Genoways and R. J. Baker, editors. Biological Investigations in the Guadalupe Mountains National Park, Texas. National Park Service Proceedings and Transactions Series Number Four.

Brown, J.K., and J. K. Smith, editors. 2000. Wildland Fire in Ecosystems: Effects of Fire on Flora. Gen. Tech. Rep. RMRS-GTR-42-vol. 2. USDA Forest Service, Rocky Mountain Research Station, Ogden, Utah. 257 p.

Buffington, L. C., and C. H. Herbel. 1965. Vegetational changes on a semidesert grassland range from 1858 to 1963. Ecological Monographs 35:139-164.

Carlsbad Caverns National Park. 1995. Carlsbad Caverns National Park's Fire Management Plan. April, 1995. National Park Service. 60 p. + appendices.

Cornelius, J. M. 1988. Fire effects on vegetation of a northern Chihuahuan Desert grassland. $\mathrm{PhD}$. dissertation, New Mexico State University, Las Cruces. 173 p.

Cox, J. R. 1988. Seasonal burning and mowing impacts on Sporobolus wrightii grasslands. Journal of Range Management 41:12-15.

Dick-Peddie, W. A. 1993. New Mexico Vegetation: Past, Present and Future. University of New Mexico Press, Albuquerque. 244 p.

Gebow, B. S., and W. L. Halvorson. 2001. Search, Compile, and Analyze Fire Literature and Research Associated with Chihuahuan Desert Uplands. Final Report to Carlsbad Caverns National Park. School of Renewable Natural Resources and USGS Sonoran Desert Field Station, University of Arizona. Tucson. 239 p.

Gebow, B. S., and W. L. Halvorson. 2002. Fire History of Carlsbad Caverns, New Mexico. Final Report to Carlsbad Caverns National Park. School of Renewable Natural Resources and USGS Sonoran Desert Field Station, University of Arizona. Tucson.

Gelbach, F. R. 1967. Vegetation of the Guadalupe Escarpment, New Mexico-Texas. Ecology 48:404-419.

Gelbach, F. R. 1981. Mountain Islands and Desert Seas: A Natural History of U.S.-Mexican Borderlands. Texas A \& M University Press, College Station. 298 p.

Goldman, D. 1994. Fire in national parks. Contact: Southwest Region Interpreter's Newsletter (NPS) 19:213. 
Grover, H. D., and H. B. Musick. 1990. Shrubland encroachment in southern New Mexico, U.S.A.: an analysis of desertification processes in the American Southwest. Climatic Change 17:305-330.

Humphrey, R. R. 1974. Fire in the deserts and desert grassland areas of North America. P. 365-401 in T. T. Kozlowski and C. E. Ahlgren editors. Fire and Ecosystems. Academic Press, New York.

Kaib, M., C. H. Baisan, H. D. Grissino-Mayer, and T. W. Swetnam. 1996. Fire history in the gallery pine-oak forests and adjacent grasslands of the Chiricahua Mountains of Arizona. P. 253---264 in P. F. Ffolliott, L. F. DeBano, M. B. Baker, Jr., G. J. Gottfried, G. Solis-Garza, C. B. Edminster, D. G. Neary, L. S. Allen, and R. H. Hamre, Technical Coordinators. Effects of Fire on Madrean Province Ecosystems. USDA Forest Service General Technical Report RM-GTR-289. Fort Collins, CO.

Kittams, W. H. 1972. Effect of fire on vegetation of the Chihuahuan Desert region. P. 427-444 in Proceedings Annual Tall Timbers Fire Ecology Conference, June 89, 1972.

Leopold, A. S., S. A. Cain, C. M. Cottam, I. M. Gabrielson, and T. L. Kimball. 1963. Report of the advisory board on wildlife management. National Parks Magazine, Insert 4-63, April:I-VI.

Marston, E. 1996. Raising a ranch from the dead. High Country News 28 (April 15, 1996).

Moir, W. H. 1982. A fire history of the high Chisos, Big Bend National Park, Texas. Southwestern Naturalist 27:87-98.

Mutch, R. W. 1994. A Return to Ecosystem Health. Journal of Forestry (November 1994):31-33.

Mutch, R. W. 1995. Need for more prescribed fire: but a double standard slows progress. Presented at Environmental Regulation and Prescribed Fire Conference, March 14-17, Missoula, MT.
Neuenschwander, L. F., H. R. Wright, and S. C. Bunting. 1978. The effect of fire on a tobosagrass-mesquite community in the Rolling Plains of Texas. Southwestern Naturalist 23:315-338.

Pope, J. 1855. Exploration of a Route for the Pacific Railroad near the Thirty-second Parallel of North Latitude, from the Red River to the Rio Grande. Explorations and surveys for a railroad route from the Mississippi River to the Pacific Ocean. War Department.

Pyne, S. J. 1984. Introduction to Wildland Fire: Fire Management in the United States. John Wiley \& Sons, New York. 455 p.

Swantek, P. J., W. L. Halvorson, and C. R. Schwalbe. 1999. GIS database development to analyze fire history in southern Arizona and beyond. Technical Report No. 61, U.S. Geological Survey, Cooperative Park Studies Unit, University of Arizona, Tucson. 43 p.

Western Regional Climate Center. 2001. Carlsbad Caverns, NM (291480): Period of Record Monthly Climate Summary, 2/1/1930 to 12/31/2000. WRCC, NOAA (sponsoring agency) and Desert Research Institute of the University and Community College System of Nevada (host institution). www.wrcc.dri.edu August 23, 2001.

Wright, H. A. 1990. Role of fire in the management of Southwestern ecosystems. P. 1-5 in J. S. Krammes, technical coordinator. Effects of Fire Management of Southwestern Natural Resources. General Technical Report RM-191. USDA Forest Service, Rocky Mountain Forest and Range Experiment Station. Fort Collins, CO. 293 p.

York, J. C., and W. A. Dick-Peddie. 1969. Vegetation changes in southern New Mexico during the past hundred years. P. 157-166 in W. G. McGinnies and B. J. Goldman, editors. Arid Lands in Perspective. University of Arizona Press, Tucson. 421 p. 


\title{
Appendix 1. Reviews of papers, reports, and book chapters relevant to fire manage- ment in the northern Chihuahuan Desert.
}

\author{
Ahlstrand, G. M. 1979. Preliminary report on the ecology of fire study, Guadalupe Mountains and Carlsbad \\ Caverns National Parks. P. 31-44 in H. H. Genoways and R. J. Baker, editors. Biological Investigations in the \\ Guadalupe Mountains National Park, Texas. National Park Service Proceedings and Transactions Series \\ Number Four.
}

Affiliation of author(s): Research ecologist at Carlsbad Caverns

Ecological perspective: This research intended to study effects of fire on vegetation, in light of relatively new (1972) policy to allow fires to burn in designated areas.

Study location, description, and timing: Locations were Guadalupe Mountains and Carlsbad Caverns national parks. The Carlsbad portion of the study measured vegetative cover in 7 burned and 7 unburned control plots (25 x 50 m "permanent" plots). Burn sites were determined by examining park fire records. Carlsbad burn study plots were in "succulent desert formation." This paper presents a single set of coverage measurements taken during the summer of 1974. Two fires were dated to 1968 , three to 1971 , and one was a question mark. Ahlstrand (1982) reports the unknown date was determined to be 1967. Thus, sampling for 3 sites was $6-$ 7 years post-fire, and for 4 sites, 3 years post-fire.

Plant species addressed: This document does not state how many species were identified, but the 1981 Ahlstrand volume (see other listings under his name) mentions that
95 species were sampled. Results were compiled by growth form: grasses, forbs, woody shrubs, stem succulents/rosette shrubs. Pairs of burned and unburned plots averaged less than $50 \%$ overlap in species composition.

Other context and important points: The paper acknowledges vegetation changes in the area based on accounts of Pope (1854), old photos, and long-time residents, but it also cites the complicating roles of grazing, fire history, water table fluctuations, and climate change. The fires considered here were larger than 0.1 acre, but otherwise not extensive. When a 9150-acre fire in 1974 was removed from a fire history dataset (19401974) that appears in this paper, the average fire size in the park was 6.6 acres over that time period, for natural and human-caused fires.

Results/conclusions relevant to fire management planning: The table below summarizes the directions of coverage results for 1974 readings. The author states, "It was not possible to identify the boundaries of burns that occurred prior to 1968." One site was later dated to 1967 , but the implication is recovery in 7 years.

\begin{tabular}{|c|c|c|c|c|c|c|}
\hline \multirow[b]{2}{*}{ \# plots: } & \multicolumn{3}{|c|}{ Coverage: $1967-1968$ fire plot pairs } & \multicolumn{3}{|c|}{ Coverage: 1971 fire plot pairs } \\
\hline & burn $>$ control & burn $=$ control & burn $<$ control & burn $>$ control & burn $=$ control & burn $<$ control \\
\hline graminoids & 3 & 0 & 0 & 1 & 1 & 2 \\
\hline forbs & 2 & 1 & 0 & 1 & 1 & 2 \\
\hline woody shrubs & 2 & 0 & 1 & 1 & 1 & 2 \\
\hline $\begin{array}{l}\text { stem succulents } \\
\text { or rosettes }\end{array}$ & 0 & 0 & 3 & 0 & 0 & 4 \\
\hline
\end{tabular}

Ahlstrand, G. M. 1981. Ecological role of fire in the Guadalupe Mountains region. P. 102-125 in G. M. Ahlstrand, principal investigator. Ecology of fire in the Guadalupe Mountains and adjacent Chihuahuan Desert. Carlsbad Caverns and Guadalupe Mountains National Parks, Carlsbad, NM.

Affiliation of author(s): Research ecologist at Carlsbad Caverns

Ecological perspective: This paper attempts to address the historic as well as modern role of fire in park ecosystems. Ahlstrand suggests 150 years of intense use by humans has altered densities of plant species but not composition (shift from grasses to shrubs).

Study location, description, and timing: The paper looks at the "Guadalupe Mountains region." It was not based on a field study. 
Plant species addressed: The role of fire is discussed in low desert, grassland-mountain shrub, canyon woodland, and forest communities

Other context and important points: During the last 100 years springs and rivers have dried up and water tables have dropped in southeast NM and west TX; irrigation and increased runoff due to overgrazing are likely to blame, but a 1930s earthquake stopped spring flow as well. Regressions of 10 -year moving average precipitation over time show precipitation decreases at Carlsbad, El Paso, and Las Cruces between 1900 and 1980. Tree ring data are presented to show a drying trend over the last several hundred years.

Early observers in the region (Don Antonio Cordero in 1796, Pope in 1854, local oldtimers) provide anecdotes about Apache use of fire. The author lists some likely explanations, many of which are like modern reasons: clear out underbrush, reduce fuel loads and prevent destructive fires, improve livestock forage (others include surrounding prey, create small firewood supplies, promote growth of useful plants, allow clear views).

\section{Results/conclusions relevant to fire management} planning: The author thinks fire was present, but never important, in low desert communities. In 1980, there was little evidence of recent fire in these communities. Cessation of grazing has allowed grasses to build back up to where fire may spread under the right weather conditions. Many species can resprout after burning, and "Rock outcrops and fuel discontinuities would allow islands of vegetation to escape burning."

Mountain shrub communities have expanded at the expense of grasses because of soil erosion caused by overgrazing. Lack of fire scars and size of juniper stems indicate extensive fires have been infrequent in modern times. Fuels have built up with removal of livestock, and more frequent, extensive fires should favor spread of grasses. Most shrubs resprout after fire; frequent fire keeps them small.

Fire in canyon woodland ("... disjunct strips of woodland vegetation occur along the drainages of major canyons in the two parks... usually bordered by mountain shrub communities") had been little studied in 1980, but the communities have obviously burned, given the presence of fire scars. Campers in canyons cause fires that spread up into mountain shrublands; lightning fires in shrublands spread down into canyons.

The forest section of the paper states that the nonsprouting juniper species thought to be susceptible to fire (J. monosperma and $J$. scopulorum) had not been damaged by recent fires. Sprouting junipers are extremely difficult to kill with fire, but the years it takes to attain previous coverage after fire allows grasses to spread.

\section{Ahlstrand, G. M. 1981. High country fire history. P. 1-22 in G. M. Ahlstrand, principal investigator. Ecology of fire in the Guadalupe Mountains and adjacent Chihuahuan Desert. Carlsbad Caverns and Guadalupe Mountains National Parks, Carlsbad, NM.}

\author{
Affiliation of author(s): Research ecologist at Carlsbad \\ Caverns
}

Ecological perspective: "The absence of fire in the recent past has permitted thickets of conifers to become established in the understory throughout the high country. It was not known if this represents a natural phase in the life cycle of the forest, or if it resulted from European man's activities in the area during the past century."

Study location, description, and timing: The study took place in the Guadalupe Mountains National Park "high country." Historical information (back to mid-19 ${ }^{\text {th }}$ century) was collected from the literature and old-timers. A tree ring chronology (back to A.D.1668) was constructed from Douglas fir cores. A ponderosa pine chronology dating to 1515 from Cloudcroft, NM, was used on samples predating 1668.

Plant species addressed: Main elements of the "relict mixed conifer forest" include Pseudotsuga menziesii, Pinus strobiformis, and $P$. ponderosa. Dry south-facing slopes support $P$. ponderosa, Juniperus deppeana, and $P$. edulis.

Other context and important points: Ahlstrand defined "fire year" as any year with $\geq$ one sample scarred by fire. A "major fire" scarred $\geq 20 \%$ of the samples, with at least 2 samples $\geq 2 \mathrm{~km}$ apart. He sampled 49 P. strobiformis.

Results/conclusions relevant to fire management planning: Seventy-one of the years between 1496 and 
1980 were fire years. Small fires were more common before the mid-1800s. The mean interval between fires was 4.7 years during 1554-1842; the interval more than doubled 1842-1922. Sixty-three of the 71 fire years occurred before 1850 . Fourteen major fires occurred 1696-1922 (mean interval 17.4 years). Until the $20^{\text {th }}$ century, 30 years was the maximum interval between major fires.
Decrease in fire frequency after mid-1800s is associated with increase in Europeans in area and fewer Apaches (who may have been responsible for some of the preEuropean fires). The last major fire was in 1922; after that grazing probably reduced the accumulation of cured grasses that helped carry fire. At the time of the study, the mixed conifer forest was overdue for another major fire, and the perpetuation of the forest was "...dependent upon finding an effective means to reduce fuel loads while saving most of the trees in the canopy."

Ahlstrand, G. M. 1982. Response of Chihuahuan Desert mountain shrub vegetation to burning. Journal of Range Managment 35:62-65.

\author{
Affiliation of author(s): Research ecologist at Carlsbad \\ Caverns
}

Ecological perspective: "Little ... has been reported concerning the effects of fire on vegetation of the Chihuahuan Desert." Paper reviews desert plant fire effects literature and states the current study is addressing longer-term response. It discusses individual species, but presents results as change in overall plant coverage on plots.

Study location, description, and timing: Carlsbad Caverns "mountain shrub community." Seven pairs of burned and unburned sites were studied in 1974; 3 fires had occurred 6-7 years previously (in 1967-1968), and 4 fires had occurred 3 years previously (in 1971).

Plant species addressed: Ninety-five species were sampled on 7 paired sites. Specific discussion is aimed at redberry juniper, whiteball acacia, catclaw mimosa, skeleton goldeneye, sotol, sacahuista, lechuguilla, prickly pear, wavy cloakfern, black grama, hairy tridens, slim tridens, plains lovegrass, three-awn and other grasses.
Other context and important points: Controls were set up after-the-fact in 1974.
Results/conclusions relevant to fire management planning: This paper summarizes results (that are in Ahlstrand 1979) by the ages of the burns. For three-year burns, total cover was down $18 \%$ relative to unburned plots. For 6-7-year-old sites, total cover was up 5\%.
"Although the majority of species encountered in this study have developed fire-surviving adaptations, extensive fires have not been frequent in this vegetation type, at least in recent times." Ahlstrand argues that grazing from the late 1800s through the mid-1900s decreased grass cover that carries fire and caused a vegetation shift toward shrubs. Thirty years of fire suppression in the post-grazing era have allowed grasses to come back while shrubs are still going strong. "With periodic burning of perhaps every 10 to 15 years in this community, grasses can be expected to increase as scrub cover is reduced. In the absence of additional fires, coverage by shrubs can be expected to slowly increase again at the expense of grasses."

Baker, M. B., Jr. 1990. Hydrologic and water quality effects of fire. P. 31-42 in J. S. Krammes, technical coordinator. Effects of Fire Management of Southwestern Natural Resources. USDA Forest Service Gen. Tech. Rep. RM191. Fort Collins, CO.

Affiliation of author(s): USDA Forest Service research hydrologist, Arizona State University

Ecological perspective: This review piece distinguishes between wildfire and prescribed burn effects where it can.

Study location, description, and timing: The article focuses on the Southwest.

\section{Results/conclusions relevant to fire management} planning: This paper discusses six hydrologic processes relative to fire in the Southwest.

- Interception of precipitation: "The effectiveness of vegetative cover in preventing soil detachment is directly proportional to the amount of cover." Prescribed burns in forests generally consume part of the fuel load on the ground but not canopy and thus affect interception very 
little. They reduce the water storage capacity of the forest floor. Wildfires consume canopy as well as fuels near the ground and have a greater impact on interception. In chaparral and grasslands, "canopy" and ground layers burn, thus effects of prescribed burns and wildfires are similar. Burning these types under cool, moist, non-windy conditions creates a patchy burn with intermixed intact and consumed areas, hence mixed interception effects.

- Infiltration and overland flow: Fire commonly results in decreased infiltration and increased overland flow (OF). Ground cover and soil qualities determine normal rates. Soil organic matter, important for "maintaining aggregate stability and soil structure," thus a major factor in infiltration, starts to change at $200^{\circ} \mathrm{C}$ and is destroyed at $450^{\circ} \mathrm{C}$. Site microclimates are changed by fire, and they in turn affect infiltration and $\mathrm{OF}$ - exaggerated temperature extremes cause more soil freezing, soil water depletion, and faster snowmelt. Intense fires can create non-wettability in soil that inhibits infiltration and increases OF. Prescribed burning that results in a mosaic of burned and unburned patches has little effect unless slopes are steep; there would be greater OF on steep slopes and slower reestablishment of vegetation. Wildfires cause huge increases in OF in chaparral, where $\mathrm{OF}$ on intact watersheds is frequently negligible. Severe flooding declines after 3 years in CA chaparral, and normal stormflows decline in 5-10 years after burning. - Soil Water Storage: With less vegetation taking up water after a fire, more water stays stored in the soil in the growing season. This result assumes the "soil mantle is recharged to capacity or near capacity during the springtime."

- Snow Accumulation and Melt: No studies were found to document effects, but the author proposes that more snow accumulates in burned areas due to less canopy interception, and that darkened surfaces would "....increase longwave radiation to the snowpack, thereby accelerating snowmelt..."

- Surface Erosion: Erosion is "episodic transport" of sediment from a source through a channel system mostly caused by "big" storms in the Southwest. Erosion's episodic nature makes it difficult to determine normal rates. "Large areas cleared by fires are vulnerable to erosion and can yield substantial amounts of eroded materials if subjected to large, high-intensity summer storms immediately after exposure. Erosion during the winter season is usually less." Fire increases soil erodibility in AZ chaparral "because of the volatilization of soil organic matter and destruction of soil aggregates." Prescribed burning should cause less sediment production than wildfire because the mosaic pattern restricts the extent of fire effects. Erosion effects also depend on slope and degree of removal of protective litter layers. Mass soil slippage can occur after intense fires where slopes are steep and rainfall heavy.

- Downstream Effects: Summer storms after wildfires in the Southwest produce increased discharges but not for long. "Intermittent streamflow prior to burning can become continuous" [presumably because of fewer plants taking up water]. Detecting increased flows some distance from fire locations is difficult. Effects on water quality include increased sediment load and altered chemistry. Volatilized plant nutrients are deposited as ash on the soil surface and ultimately can be washed or leached away. Soluble nutrients are easily lost by erosion. "Abovenormal movement of nutrients to streams by surface erosion and leaching has the potential for impairing quality of surface water for municipal purposes, causing eutrophication of aquatic habitats, and lowering of site productivity."

Buffington, L. C., and C. H. Herbel. 1965. Vegetational changes on a semidesert grassland range from 1858 to 1963. Ecological Monographs 35:139-164.

\author{
Affiliation of author(s): USDA Jornada Experimental \\ Range, New Mexico
}

Ecological perspective: The study was interested in historically documenting shrub encroachment on the Jornada, once an extensive semi-desert grassland.

Study location, description, and timing: The study compares vegetation surveys conducted in 1858, 1915, 1928, and 1963 on the Jornada plain, just north of Las
Cruces, NM. Elevation ranges from 3900 to $4500 \mathrm{ft}$. A vegetation map was extrapolated for the 1858 survey based on notes and later maps. Results were tabulated by computing map areas occupied by the three species (and combinations) named below.

Plant species addressed: The authors focused on changes in creosotebush, mesquite, and tarbush. They deduced modern plant names from the common 1858 usage based on plant physical features and ecology. 
Other context and important points: Livestock were driven across the plain as early as the late 1600s. Cattle operations were present at the time of the 1858 survey, and numbers ranged from 4,632 head 1915-1916 to 10,006 in 1953. Rainfall averaged 9.1 in per year at the Jornada headquarters in 1962, but distribution around the area was typically uneven.

\section{Results/conclusions relevant to fire management} planning: Acreage containing no creosotebush, mesquite, or tarbush declined through the study period $(83,625 \mathrm{ac}$ in 1858 to 0 in 1963). The authors break down results by shrub species, and by changes over soil types. Five factors had been suggested in the literature at the time of the study as the causes of the shifts:

Climate change: Drying and warming would favor shrubs over grasses.

Grazing: Overgrazing has killed grasses and altered soils making the shrub shift irreversible. Livestock also spread mesquite seed.
Rodents and rabbits: Increases in effects of these animals are more likely a result of range deterioration than a cause.

Fire suppression: "In the extensive reviews of literature regarding the Jornada del Muerto. . .no record of extensive fires has been found." There are no causal records of fire and no mention of it from early travelers. There is some disagreement about whether the range ever contained enough fuel to carry fire, but there is no evidence that fire recently played a major role.

Plant competition: If plant competition for moisture was an important factor maintaining grasses, then selective grazing would favor shrubs.

The authors suggest that in general (over the diverse areas of the range) grazing weakened grasses, allowed shrubs to invade, and exposed soil. Trampling also disturbed shallow soils. As soils eroded, conditions favoring grasses were altered, and cessation of grazing did not reverse shrub incursion. Creosote, mesquite, and tarbush showed different responses in different areas.

Cable, D. R. 1973. Fire effects in Southwestern semidesert grass-shrub communities. Proceedings of the Tall Timbers Fire Ecology Conference 12:109-127.

\author{
Affiliation of author(s): Range Scientist, USDA Forest \\ Service, Tucson
}

Ecological perspective: This paper views fire as a semidesert grassland management tool and discusses how it affects undesirable shrubs and forage.

Study location, description, and timing: The paper describes work carried out "intermittently" between 1949 and 1972 at the Santa Rita Experimental Range south of Tucson, AZ. Prescribed burns were conducted and fire effects documented.

Plant species addressed: Velvet mesquite (Prosopis velutina), jumping cholla (Opuntia fulgida), cane cholla (O. spinosior), prickly pear (O. englemannii), burroweed (Isocoma [Aplopappus] tennuisectus), Larchleaf goldenweed [turpentine bush] (Ericameria [Aplopappus] laricifolius), false-mesquite (Calliandra eriophylla), velvet-pod mimosa (Mimosa dysocarpa), needle grama (Bouteloua aristidoides), sixweeks three-awn (Aristida adscensionis), [spidergrass] (A. ternipes), Santa Rita threeawn (A. californica [glabrata]), Rothrock grama ( $B$. rothrockii), Arizona cottontop (Digitaria [Triachachne] californica), tanglehead (Heteropogon contortus), black grama (Bouteloua eriopoda), and Lehmann lovegrass (Eragrostis lehmanniana).

Other context and important points: The area is overrun with non-indigenous Lehmann lovegrass (Eragrostis lehmanniana).

\section{Results/conclusions relevant to fire management planning: \\ Mesquite: Fire might be a tool to prevent mesquite} invasion, but the plant is relatively resistant to burning. Mature trees are hard to kill. It has a "...marked ability to sprout from basal stem buds or crown buds if the fire is not too severe." The research on the Santa Rita has shown mesquite most susceptible to fire during the hottest, driest time of the year, late spring and early summer. In one fire, mesquite kill was twice as high in a Lehmann-dominated area compared with black grama (and the author suggests Lehmann as an anti-mesquite tool).

Cacti: Fire-kill was observed to be strongly tied to fuel accumulation. One study showed roughly 30-60\% kill, depending on the species (list above) one year, and three years later in the same place a fire resulted in no significant change in cactus densities, probably because sufficient fuel hadn't built up in three years. Cholla, but 
not prickly pear, might increase after a cool fire from sprouting of fallen, but otherwise intact, joints.

Burroweed: "Burroweed..., an unpalatable half-shrub, common in the semi-desert, is easily killed by burning." It does not sprout from roots, and its resinous foliage and fine stems don't have a chance in a fire. However, the species will germinate readily if the fire is followed by wet winters. Thus, repeated burning is needed to keep it out.

Creosotebush: Maximum mortality of creosotebush occurred after June burning, with young plants showing greatest effects. " ...[M]ature stands of creosotebush rarely contain enough herbaceous fuel to carry a fire." Turpentine bush: This species showed little recovery two growing seasons after fire.

False-mesquite and velvet-pod mimosa: Severely damaged plants produced abundant basal sprouts and had recovered by the second growing season.

Needle grama and sixweeks three-awn: Burning had little direct effect on herbage production in these annual grasses the year following fire unless fire was followed by a wet summer. In dry years, perennial grasses with established root systems have an advantage. Seeds on the ground were not damaged by the "usual" fire.

Perennial grasses (list on previous page under "Plant species addressed" beginning with spidergrass): Effects of two fires three years apart were different, most likely because of the different rainfall amounts in the summers following the fires and the lack of burroweed at the time of the second burn. Spidergrass, that tends to grow within the crowns of resinous burroweed and is tall and dry, decreased about $70 \%$ after the first burn. Lower growing, greener Santa Rita three-awn grows away from burroweed, and cover for that species increased in the first summer. Rothrock grama, Arizona cottontop, and tanglehead "were intermediate in their degree of dispersion and association with burroweed, and in their reactions to burning). A June fire burned black grama to within $1 / 8$ to $3 / 4$ inch from the root crown. Sprouting began about 3 weeks later, but only $10 \%$ sprouted, and no seedlings were found.

Lehmann lovegrass: The author describes the South African introduction's positive (range-related) attributes - drought resistance, tolerance of heavy grazing, ease of establishment, competitive superiority, and high productivity. Drawbacks are unpalatability and that it is so aggressive it can crowd out natives within 15 to 20 years. Stands are thick and make for hot fires that kill plants, but it reseeds with no problem.

Burning on semidesert ranges results in a situation where improved soil moisture for some plants through reduced competition is tempered by increased evaporation and higher surface temperatures due to removal of cover. "The fact that most burning studies in the semidesert have shown little or no permanent damage or benefit to the perennial grass stand indicates that these two opposing factors probably in most cases cancel each other out."

Cornelius, J. M. 1988. Fire effects on vegetation of a northern Chihuahuan Desert grassland. PhD. dissertation, New Mexico State University, Las Cruces. 173 p.

Affiliation of author(s): Graduate student at New Mexico State University

Ecological perspective: This three-season study sought to assess whether fire is an important maintenance factor for a desert grassland system or whether it is an infrequent disturbance. The author predicted grasses would respond positively, shrubs negatively to fire if it is important maintainer of grasslands.

Study location, description, and timing: Work took place at the Jornada LTER site north of Las Cruces. The study was carried out on $2 \mathrm{~m} \mathrm{X} 2 \mathrm{~m}$ quadrats around 60 each of 3 shrub species within a $50 \mathrm{~m}$ X $100 \mathrm{~m}$ plot. Three treatments (20 of each shrub): burn 1984, burn 1985, control. Basic design was to burn the $4 \mathrm{~m}^{2}$ shrub-centered plots and monitor recovery (measured by cover of plant species).The burns were conducted during May 1984 and
May 1985 (different plots burned different years), which the author considered the natural fire season. Plant canopy cover was estimated preburn in spring 1984. Results were measured after summer rainy seasons in September 1984, 1985, 1986.

Plant species addressed: The study primarily looked at black grama (Bouteloua eriopoda) and shrubs - jointfir (Ephedra trifurca), snakeweed (Gutierrezia microcephala [Xanthocephalum microcephalum]), and prickly pear Opuntia violacea).

Other context and important points: Rainfall in 1983, 1984, 1985, 1986 met or exceeded the annual average of $215 \mathrm{~mm}$ (station $1 \mathrm{~km}$ away). "Upper piedmont grassland zone" was considered mostly ungrazed. Study also found that Lehmann lovegrass recovered at a faster rate relative to its preburn cover than did black grama. 
Results/conclusions relevant to fire management planning: Black grama was slow to return to quadrats (estimated 6-8 years to return to pre-burn cover), and mortality of jointfir and prickly pear was low. Snakeweed mortality was high, but so was post-fire seedling establishment for the species. "There was increased species diversity even three years after burning due to decreased grass cover and increased cover of perennial forbs and annuals." These results generated the conclusion that fire was not an important maintenance factor. "Instead, a widespread, intense fire would likely have been a severe disturbance that could have caused decreased abundance of grasses and increased abundance of shrubs, thus possibly enhancing desertification rather than preventing it."

\section{Cox, J. R. 1988. Seasonal burning and mowing impacts on Sporobolus wrightii grasslands. Journal of Range Management 41:12-15.}

\section{Affiliation of author(s): USDA ARS, Tucson}

Ecological perspective: This study looked at the effects of burning and mowing in different seasons relative to forage quantity and quality.

Study location, description, and timing: The study began in January 1980 in a big sacaton grassland about 80 $\mathrm{km}$ south of Tucson at $1370 \mathrm{~m}$ elevation (average precipitation $400 \mathrm{~mm}$ ). The 2-ha study area was fenced within a 500-ha, grazed pasture with a long history of grazing. Ten $0.3 \times 2.0 \mathrm{~m}$ areas were presampled (all above-ground grass harvested and weighed) then 20 plots were sampled at 6 -week intervals after treatments for 3 years. Green and dead material were analyzed for nitrogen content.

Plant species addressed: big sacaton (Sporobolus wrightii).

Other context and important points: Fire scars were observed on nearby trees, and oldtimers told of lightning fires in 1920, 1935, and 1950, and controlled burns every 5-10 years $1935-1975$.

Results/conclusions relevant to fire management planning: Plants defoliated in the summer recovered faster than those treated in fall or winter. Recovery to pretreatment levels of plots mowed or burned in summer took 2-3 years. However, "[b]urning and mowing at any season removes green big sacaton forage available to livestock and reduced the amount of green forage for at least the next two years." The results hold for rainfall above, below, or equal to the long-term average. Quality (nitrogen content) temporarily increased with mowing and burning, but the effect disappeared after 6 weeks.

Big sacaton stands along semi-desert grassland riparian areas occupy about $5 \%$ of their pre- 1880 range. The grasses helped spread floodwaters in low lying areas, create perennial streams, and prevent channelization. Leaving plants alone, especially in fall and winter, is recommended.

Daubenmire, R. 1968. Ecology of fire in grasslands. Advances in Ecological Research 5:209-266.

Affiliation of author(s): Washington State University

Ecological perspective: At the time, "recognition of the ubiquity and importance of burning in determining the distribution and form of many plants, as well as the composition of vegetation has been slow to develop."

Study location, description, and timing: In an era of forest fire suppression, this review article sought to clarify the very different grassland fire picture.

Plant species addressed: The paper discusses every kind of grassland imaginable.
Other context and important points: Much "natural" vegetation all over the world has actually been maintained by human-induced fires or by human fire suppression. Benefits of fires in grasslands were understood early, but the forest fire suppression movement (that arose to prevent economic loss) carried over into grasslands for a period in the first third of the $20^{\text {th }}$ century.

\section{Results/conclusions relevant to fire management} planning: Note- trends reported below have come from varying numbers of studies.

- Grass fires spread quickly, but fire temperatures are independent of fire size. Heat released is a function of 
weather, topography, and fuel characteristics. Forest fires are much hotter (high temperatures cited were $1,150^{\circ} \mathrm{C}$ for forest; $720^{\circ} \mathrm{C}$ for grass, though $<600^{\circ} \mathrm{C}$ is more common). Backfires are hotter closer the ground than headfires.

- Drier soil reaches higher surface temperatures in grass fires, but moister soil is better at conducting heat downward. Highest temperatures are usually above ground level and short-lived, thus shallow buds and seeds can escape damage. Little heat penetrates the soil surface.

- Soil surface and surface layer (cites data down to 15 $\mathrm{cm}$ ) temperatures are much higher in burned areas due to removal of plants and litter that previously intercepted sun and insulated soil.

- Decomposition slows in burned grasslands because burned new growth tends to stand upright and the soil surface is drier. Normal litter layer is slow to recover. Results for soil organic matter are mixed (sometimes higher and sometimes lower after fire).

- Burning promotes soil erosion in dry grasslands; recommendation is to conduct burns as close to the start of the growing season as possible, though hazards of such action at typically very dry times are acknowledged.

- Soil moisture changes both directions following grassland fires. In some areas where vegetation intercepts much precipitation or where transpiration is a big factor, soil moisture can increase following fire. Where summer precipitation prevails, soil moisture generally decreases in burned grasslands.

- Nutrient release by grassland fires is small compared with forest fires, but "fertilizer" effects are suspected.

- The temporary elevation of $\mathrm{pH}$ (due to abundance of alkaline metals in plant ash- $-\mathrm{Ca}, \mathrm{Mg}$. $\mathrm{K}$ ) is a widespread observation post-fire in mesic grasslands but not in drier areas (southeast AZ and eastern Idaho).

- Fire releases macronutrients (other than nitrogen) all at once to the soil surface where they are subject to washing, blowing, or leaching away.

- Many studies show increases in nitrogen from grass fires, others show no change, and a few show decreases. If plant material burns to white ash, the nitrogen is completely volatilized. If charred litter remains, nitrogen usually increases. Nitrogen levels may be increasing with elevated post-fire soil temperatures and microbial activity or with post-fire invasion by legumes.

- The microorganisms in the soil had not received a lot of attention at the time of this review, but given that grassland fires do not raise soil temperatures much just below the surface, the author thought heat effects were negligible. Fungi are killed by fire but bounce back quickly. Soil fauna are reduced, possibly mostly affected by changes in soil porosity.
- Grassland fires are very hard on ground-nesting birds, but insectivores are quick to find insects flushed by advancing fires.

- Rodents lose food and cover in grass fires but are sheltered in burrows.

- Young grassland ungulates frequently perish in fires. Burning for range recovery can end up attracting animals to tasty new growth which hampers recovery. It can be an advantage where an undesirable species may be palatable only just after a burn.

- Damage to plants is a function of growth form (rhizomatous and annual grasses do better than suffrutescent [slightly woody or shrubby] grasses), plant temperature at the time of the fire, phenology (perennials whose new foliage has just reached full size fare worse), the height of the maximum fire temperature, fuel quantity, habitat degradation (plants fare worse in eroded habitats), dryness (plants fare worse in drier climates). Positions of buds and seeds are crucial - the higher they are, generally the more damage they incur. Grass species have been observed to respond differently to fires in different locations. Damage may be indirect - a fire might hasten growth only to make the plant more susceptible to drought.

- Explanations vary for increases in nutritional value of grasses after fire. "Increased soil nutrients" is not automatic. Increases in value of individual plants may correspond with overall thinning of a stand whose cumulative nutritional value is less than before the fire. Fire may remove senescent growth from plants that was diverting resources from new shoots. Fire may stimulate roots to bring up more nutrients. Post-burn changes in grass composition are generally temporary.

- Grazing stresses plants recovering from fireunlimited access to new growth severely taxes root reserves.

- Moisture content has been found to be higher in new post-burn shoots. These shoots frequently appear 1-3 weeks earlier the season following fire, possibly because of increased soil temperatures. Other stages may also come early (flowering, fruiting).

- Species that increase flowering after fires are distinct from species that decreased flowering. Frequently species that decrease flowering increase vegetative growth. Fire effects on sizes of plants and plant parts are less predictable.

- Removal of litter can cause growth spurts similar to fires, suggesting that shading of new leaves by litter retards growth. Higher productivity and litter accumulation in wetter grasslands may explain reliance on fire for renewal in those habitats."

- Fire-sensitivity in annuals depends on seed survival. Fire generally kills seeds that have not dropped off plants, but seeds on the ground frequently survive and germinate 
earlier. Earlier germination may be a function of environment rather than changes in seeds.

- Community composition will shift toward species less susceptible to fire with frequent fires. Repeated burning thins or eliminates woody species that do not resprout. Fire commonly favors forbs over grasses; in "dry steppe annuals may gain at the expense of perennials." Very rarely fire has no effect on composition. Fire may increase diversity as opportunistic invaders arrive in newly open areas within otherwise intact (in terms of number of species) stands. Fire studies need to be very specific to plant community.

- Density of perennial grasses varies after fire; density of annual grasslands tends to drop due to seed destruction. Sizes of widely spaced annuals increase dramatically, seed production rises, and normal densities are reestablished by the next season. In general, fire causes a spurt of productivity in mesic grasslands and temporarily depresses it in drier areas of the "midcontinent steppe," but farther west "stimulation rather than injury is the rule" (which may have to do with a shift toward more winter precipitation). Productivity benefits to grazing will be reaped only if grazing has been light enough to allow enough productivity to sustain a fire!

- Timing is everything. The author reemphasizes how season affects all factors discussed and remarks that natural fires generally occur at driest times, while burning for management take place at other times, depending on goals.

Dick-Peddie, W. A. 1993. New Mexico Vegetation: Past, Present and Future. University of New Mexico Press, Albuquerque. 244 p.

\section{Affiliation of author(s): New Mexico State University Biology Department}

Ecological perspective: This book is a review of the literature (through 1990) on New Mexico vegetation types, with discussions of change where information exists. This review covers the sections in Chapter 7 ("Grassland Vegetation") on Desert Grassland and in Chapter 8 ("Scrubland Vegetation") on Montane Scrub.

Other context and important points: The author views this book as "the culmination" of his 34 years of work as a NMSU plant ecologist interested in vegetation change.

\section{Results/conclusions relevant to fire management planning:}

Desert Grassland: This vegetation type is "transitional" as is apparent from other names for it appearing in the literature - semi-desert grassland, desert-grassland transition, desert savanna, desert-plains grassland, desert shrub grassland, and grassland transition. The author includes desert scrubland areas that were previously grassland in his desert grassland category. Grazing is heavily implicated in the grassland-to-scrubland shift. Scrub that was recently grassland generally contains abundant forbs. Grassland-shrub communities containing shrubs that also dominate desert scrub communities are probably on the move toward desert scrub. Grassland- scrub with montane scrub shrubs may be a natural ecotone between montane scrub and plains-mesa grassland.

Montane Scrub: "This scrubland is found in situations where the available moisture is less than might be expected considering the altitude, latitude, and/or surrounding vegetation." It is frequently found in patches determined by substrate or exposure, but in some parts of New Mexico, including the Guadalupe Mountains, the community is extensive. It is often not obvious whether scrublands are climax vegetation types. In the case of montane scrub, many of its component shrubs are also found in other plant communities (woodlands in higher, wetter places and desert grassland or desert scrub in lower, drier places). While montane scrub species tend to become established on logged or burned montane forest sites, it is the author's opinion that the composition and extent of non-successional montane scrub has "changed little during the past 150 years."

The author says that in New Mexico, available moisture can segregate most vegetation types. He suggests that “. . . . the relationship between fire and vegetation can be very complicated" and discounts fire as a major determinant of plant community structure, a conclusion based on many of the papers in this review. 
Dwyer, D. 1972. Burning and Nitrogen Fertilization of Tobosa Grass. NMSU Agricultural Experiment Station Bulletin 595. Las Cruces, NM.

\author{
Affiliation of author(s): New Mexico State University \\ range science professor
}

Ecological perspective: This study addresses the effects of fire on tobosa grass, mainly from a range perspective.

Study location, description, and timing: The study was conducted on the Jornada Experimental Range, 19661970. Treatments consisted of (1) burning and (2) burning with subsequent fertilization. In addition to control plots, there was also a treatment of unburned plots with fertilizer July 15. Any given plot was burned only once; plots were burned June 15, July 15, August 1, and December 1. Fertilized plots were treated annually. Plots were $15 \mathrm{ft}$ x $20 \mathrm{ft}$. "....four replications."

Plant species addressed: tobosa grass (Pleuraphis [Hilaria] mutica).
Other context and important points: Rainfall during five study years ranged from $30 \%$ below long-term average to $10 \%$ above.

Results/conclusions relevant to fire management planning: After the first growing season, only plots burned December 1 that received $60 \mathrm{lbs}$ nitrogen per acre and the unburned plots that were fertilized July 15 showed increased production (however, rainfall was $26 \%$ below long-term average). In 1967 (after two post-burn growing seasons) only the June burn/unfertilized treatment showed production lower than control. In 1968, "....detrimental effects of the burn treatment had apparently disappeared," and fertilized plots showed more production than unfertilized. "Increases in dry matter production of tobosa grass occurred only when nitrogen was applied. Burning, by itself, either had no effect on production or reduced it." Burning in June reduced production the most.

Gelbach, F. R. 1981. Mountain Islands and Desert Seas: A Natural History of U.S.-Mexican Borderlands. Texas A \& M University Press, College Station. 298 p.

\begin{abstract}
Affiliation of author(s): At the time, Gelbach was a professor at Baylor with extensive experience as an ecologist in the Borderlands (and in the Guadalupes).

Ecological perspective: This book visits many perspectives but has an underlying focus on species diversity and the impact of human actions on it.
\end{abstract}

Study location, description, and timing: Chapters form a "transect" along the border between the mouth of the Rio Grande and the Colorado River. The book is a compilation of observations made during the early 1970s and before.

Plant species addressed: A number of plant and vertebrate communities discussed in chapters that move from east to west

Other context and important points: Author believes early man hastened extinction of large mammals by killing them in large numbers as well as disrupting habitat (staking out waterholes, using fire to drive them or make areas no longer suitable). Modern man is responsible for altering vegetation patterns. He thinks diversion and depletion of water sources are having the greatest impact on species distributions in modern times.

Results/conclusions relevant to fire management planning: Gelbach suggests grazing has been the main cause of the shift from grass to shrubs in the Chihuahuan Desert (as opposed to fire suppression or increasing aridity). Chihuahuan grasslands do not encourage widespread fire - natural fires do burn woody shrubs but are stopped by rocks, lack of fuel, rain, and shifts in wind. He views the Borderlands as a place where the concept of stability means certain dominant species persist over time, but otherwise floods, drought, and fire are frequent stresses that cycle species through habitats (p. 110-111).

This book does not offer abundant fire insights but it does expand on the subtle and not-so-subtle ways humans have changed the regional landscape. Gelbach has ways of measuring everything, so his conclusions are frequently based on data, but presented in an old-time naturalist's philosophical style. Following Aldo Leopold and Joseph Wood Krutch, he says one needs to be learning from nature as one learns about nature. 
Goldman, D. 1994. Fire in national parks. Contact: Southwest Region Interpreter's Newsletter (NPS) 19:2-13.

Affiliation of author(s): Park Planner, National Park Service Southwest Regional Office, Santa Fe

Ecological perspective: The article is a review of the ecological roles of fire and human perceptions of fire as they relate to national parks.

Plant species addressed: Mostly forests.

Other context and important points: The Leopold Report and observations at parks (Sequoia example) brought home the fact that reintroduction of fire was necessary to preserve the resources whose protection was mandated by establishment of parks. The author compares predictability of fire events to rain - a good analogy in the southwest where rainfall varies widely from season to season.

\section{Results/conclusions relevant to fire management planning:}

- Forest fires are big news and media coverage makes people think whole forests rather than trees are killed by these events.
- Perception is that forests are static rather than dynamic; many seemingly "permanent" habitats are successional stages maintained by fire (meadows, aspen groves).

- Park visitors are not prepared to see fire-blackened landscapes. At Bandelier after the La Mesa fire in 1977, interpretive programs addressed the plant succession taking place.

- Smokey Bear message applies in modified formvisitors should still be careful with fire.

- Grassland-pinyon-juniper at CAVE and GUMO was invaded by cactus, mesquite, and brush as a result of overgrazing, and decrease in fires.

- Wildfires still are not welcome in national parks. "Management ignited prescribed fires" are designed to accomplish ecological goals while carefully protecting critical resources (air quality, threatened and endangered species, historic/cultural resources). "Prescribed natural fires" are allowed to burn when a lightning event coincidentally satisfies fire management plan objectives.

Grover, H. D., and H. B. Musick. 1990. Shrubland encroachment in southern New Mexico, U.S.A.: an analysis of desertification processes in the American Southwest. Climatic Change 17:305-330.

Affiliation of author(s): University of New Mexico Biology Department

Ecological perspective: A model is needed that addresses prevailing theories explaining shrub encroachment (overgrazing, fire suppression, climate change).

Study location, description, and timing: The authors derive a qualitative model from a review of the literature.

Plant species addressed: The paper looks at perennial grasslands that have been invaded by mesquite (Prosopis glandulosa) and creosotebush (Larrea tridentata). Focus on the Jornada Experimental Range north of Las Cruces and the Bootheel (extreme southwest corner of New Mexico), where encroachment studies have been conducted. Areas are lower and drier than Carlsbad.

Other context and important points: While many authors have addressed probable causes of shrub encroachment, fewer have incorporated positive feedback mechanisms into their discussions.

\section{Results/conclusions relevant to fire management planning: "Once the balance was tipped even temporarily in favor of shrub invasion, several positive feedback mechanisms functioned to perpetuate the process even though the triggering factors may have returned to their original state."}

The authors see grazing and climate change as the key causes of desertification. They cite a paper describing a drying trend for the period between 1898 and 1959 across 18 weather stations in Arizona and southeastern New Mexico, with the decrease in moisture attributable to less cool season precipitation. Though they found conclusions in the literature that fires were larger and more frequent before 1882 (when grazing rose to destructive levels), other authors found little evidence of widespread grass fires. "Fires are currently so uncommon in the mesquite and creosotebush shrublands of southern New Mexico 
and southeastern New Mexico that data on fire frequency and extent are almost nonexistent."

In the model presented in the paper, fire suppression plays a role in the acceleration of invasions, once grass cover has been depleted by grazing and drought.
Creosotebush grows on soils with near-surface carbonate horizons, and it would appear that the plant is currently occupying most of the soils suited to it in New Mexico. Further range expansion might result if currently "unsuitable" soils were eroded. Mesquite grows on a much wider range of soil types and might potentially dominate more real estate in the southern and eastern plains of New Mexico and much of western Texas.

Grumbine, R. E. 1997. Reflections on "What is ecosystem management?" Conservation Biology 11:41-47.

Affiliation of author(s): Sierra Institute, UC Santa Cruz Extension

Ecological perspective: Concept and practice of ecosystem management are still evolving. This paper describes 10 themes based on a review of literature and interviews with managers.

Study location, description, and timing: This paper is a management philosophy piece.

Other context and important points: This work is really about the process of bringing parties together and keeping them at the table to make ecosystem management decisions (and not about ecosystems).

\section{Results/conclusions relevant to fire management planning:}

- Despite omnipresent data gaps, usually enough information is available to begin to resolve problems.

- Researchers and managers need to work face to face (as opposed to just hand data to one another).
- Non-scientific questions frequently require as much data collection as scientific questions.

- Designing and funding monitoring programs need to be integral parts of management programs.

- Progress requires cooperation rather than competition; the context here is interagency, but comments apply intra-agency. Cooperation is fostered when all parties share in defining problems, and powersharing is a goal. Imbalance of power leads to little chance for success. Use facilitators rather than chairmen. Partnerships become unwieldy with too many participants.

- "Adaptive" management explores multiple rather than single causes for problems, avoids quick fixes, allows for variable ecosystems, tests techniques via multiple, modest experiments rather than single, broad designs.

- Successful ecosystem management may require changing institutional structure-especially decompartmentalizing disciplinary and program specialties.

- Resource management decisions are generally based as much (or more) on human values as on facts and logic.

Humphrey, R. R. 1974. Fire in the deserts and desert grassland areas of North America. P. 365-401 in T. T. Kozlowski and C. E. Ahlgren editors. Fire and Ecosystems. Academic Press, New York.

Affiliation of author(s): USDA Forest Serveice, Tucson and University of Arizona range management professor

Ecological perspective: Review article.

Other context and important points: The Chihuahuan Desert is more "susceptible" to fire than Sonoran.

Results/conclusions relevant to fire management planning: Despite the presence of vegetation that burns readily, there are few fires in the Chihuahuan Desert. Natural lack of fuel, grazing, and fire suppression have decreased fire frequency and encouraged growth of shrubs at the expense of grass. Tobosa flats are probably becoming more shrubby due to less fire.

In desert grasslands, shrubs, low-growing trees, and cacti were originally restricted to drainages that supported little grass or shallow soil areas. The author says that there were still range fires during the era of severe range 
overstocking in the late 1800 s. He gives fire suppression equal standing with overgrazing to explain the shift of desert grasslands to shrublands. He sees natural boundaries between grasses and shrubs delineated by precipitation-the change to shrubs occurs where there is not enough rain to grow enough grass to carry fire. The author is not convinced that fires on altered desert landscapes will restore them; shrubs have grown treelike and are hard to kill while depleted grasses offer little fuel for the process.

Kaib, M., C. H. Baisan, H. D. Grissino-Mayer, and T. W. Swetnam. 1996. Fire history in the gallery pine-oak forests and adjacent grasslands of the Chiricahua Mountains of Arizona. P. 253---264 in P. F. Ffolliott, L. F. DeBano, M. B. Baker, Jr., G. J. Gottfried, G. Solis-Garza, C. B. Edminster, D. G. Neary, L. S. Allen, and R. H. Hamre, Technical Coordinators. Effects of Fire on Madrean Province Ecosystems. USDA Forest Service General Technical Report RM-GTR-289. Fort Collins, CO.

\begin{abstract}
Affiliation of author(s): Laboratory of Tree Ring Research, University of Arizona
\end{abstract}

Ecological perspective: The authors propose that fires regularly spread into mountain canyons from adjacent grasslands. "Intercanyon synchronicity of fire dates would support this hypothesis and therefore historical fire frequencies in gallery forests provide a conservative (i.e. minimum) estimate of fire frequencies sustained in the lower semidesert grasslands." They argue that within the mountain ranges, topographic and vegetative barriers to fires discourages spreading between canyons.

Study location, description, and timing: The study was conducted in the Chiricahua and Huachuca mountains in southeastern Arizona and Sierra de los Ajos, Sonora, Mexico. Workers constructed fire histories using firescarred Apache and Arizona pine logs and stumps in pine-oak forests adjacent to grasslands. The histories extended back to the mid-1600s; analysis covered 1700-
1876. Data presented in this paper are from three sites in the Chiricahuas.

Other context and important points: This paper also reviews historical accounts of fire in the region that appear in ethnographies, early government reports, and newspaper articles. Indian use of fire corresponds with periods of war that coincide with above average fire frequencies in the Chiricahuas for those times.

Results/conclusions relevant to fire management planning: The authors found 21 out of 71 fires synchronous between Pine and Rhyolite canyons. Using fires recorded by at least 2 trees, a conservative estimate of intercanyon fire frequency of 8 years is generated. They estimate individual canyon fire frequency at 4 years and suggest the grassland fire frequency is somewhere between 4 and 8 years. Sixteen of 90 fires were recorded in both canyons plus Rustler Park, above them. These events are considered larger-scale fires.

Keeley, J. E., C. J. Fotheringham, and M. Morais. 1999. Reexamining fire suppression impacts on brushland fire regimes. Science 284:1829-1832.

\section{Affiliation of author(s): JEK-USGS Sequoia-Kings Canyon Field Station, CJF-UCLA, MM-UC Santa Barbara}

Ecological perspective: This work examines whether elimination of fire suppression has led to smaller fires.

Study location, description, and timing: The study used California Statewide Fire History Database to examine characteristics of fires before and after 1950. Oldest records date from late $19^{\text {th }}$ century. Area examined was California coast range mountains between Monterey and San Diego.
Plant species addressed: The paper offers no detailed description of vegetation or mention of individual species. A footnote says, "Fires recorded here burned predominantly in chaparral, which sometimes forms a mosaic with coastal sage scrub, grassland, oak woodland, and coniferous forests."

Other context and important points: The study presents brush area by county and (1) number of fires, (2) mean fire size, and (3) interval between fires in the same place — all three before and after 1950 . 
Results/conclusions relevant to fire management planning: In all but one county, fire frequency increased in the $2^{\text {nd }}$ half of the $20^{\text {th }}$ century. A majority of counties showed no significant change in average fire size. Rotation interval declined in all but two counties (without causing a decrease in fire size). A look at vegetation age classes burned in fires showed that the biggest fires were not necessarily burning the oldest stands. "In brushcovered landscapes of southern and central-coastal California, there is no evidence that fire suppression has altered the natural stand-replacing fire regime in the manner suggested by others." "Others" suggest that suppression allows fuels to build up; a study finding large fires slightly more abundant in southern California than in adjacent Baja California has been cited as support for this idea.

Prescribed burning of these coastal brushlands is difficult and the authors see their results as justifying not doing it. The fire season is characterized by strong, hot, dry winds that spread fires through all age classes of vegetation. Strategies to prevent fire damage might better focus on buffering the increasingly extensive urban-wildland interface.

\section{Kittams, W. H. 1972. Effect of fire on vegetation of the Chihuahuan Desert region. P. 427-444 in Proceedings Annual Tall Timbers Fire Ecology Conference, June 8-9, 1972.}

\section{Affiliation of author(s): Research biologist at Carlsbad Caverns National Park}

Ecological perspective: This paper summarizes fire effects on individual species within predominately evergreen shrub communities, with comments about species' roles in the spread of fire. It offers a few speculations about community composition over time. The author was also interested in whether fire improved plants' appeal to deer.

Study location, description, and timing: The paper presents post-burn observations for 10 natural fires that occurred 1967-1972 in Carlsbad Caverns National Park. There was no consistent monitoring schedule, but sites were generally observed within six months of the fire and three years later.

Plant species addressed: lechuguilla (Agave lechuguilla) and $A$. parryi, sotol (Dasylirion leiophyllum), Juniperus pinchotii \& J. deppeana, Rhus trilobata, Quercus undulata \& $Q$. mohriana (oak identification tentative), Cercocarpus brevifloris, Ceanothus greggii, Mimosa biuncifera, and Nolina texana. The paper contains a few comments on other shrubs and some grasses.
Other context and important points: The author states at the beginning that "a variety of opinions have been expressed regarding the role of fire in grassland versus shrubland under conditions similar to those in our area." He acknowledges that the study is a non-quantitative look with no controls.

Sotol is identified as a lightning catcher, lechuguilla and grasses as fire spreaders. Lechuguilla, large sotol, and datil yucca are the only species usually killed by fire; all others generally resprouted. Junipers are called "slow" to recover from fire (might take 25-30 years to regain full spread); all others rapid or moderate.

\section{Results/conclusions relevant to fire management} planning: A three-year study obviously does not capture the long-term picture. The author suggests a 10-year fire interval "would probably maintain the grassland aspect on those sites which are relatively favorable for grass." $\mathrm{He}$ says, "On sites at higher elevation and more severe in character...we can expect a temporary expression of grasses such as needlegrass, with opportunist shrubs such as skeleton golden eye in 2 to 3 years; and a gradual regaining of hairy mountain-mahogany cover, with quality bunchgrasses and perhaps significant establishment of desert ceanothus from seedlings in the range of 10 years." 
Affiliation of author(s): Reporter (HCN editor)

Ecological perspective: Opinion expressed in the article by fire historian Stephen Pyne of ASU (and also by the article's star, rancher Sid Goodloe) is that "...the Southwest was dominated by grasses [that carried fire everywhere] and now it's dominated by woody plants."

Study location, description, and timing: The article is a news story about a ranch near Capitan, NM. Elevation $6500 \mathrm{ft}-7200 \mathrm{ft}$. Story was written 40 years into the rehabilitation of former grassland, now pinyon-juniper woodland.

Plant species addressed: pinyon-juniper $(\mathrm{PJ})$ versus grass.

Other context and important points: Goodloe realized the abused ranch he bought in 1956 looked and functioned nothing like the land did historically and set out to bring it back to a productive state.

\section{Results/conclusions relevant to fire management} planning: The rancher believes lightning fires in grassland kept PJ at bay until enormous herds of sheep and cattle reduced grass, prevented fire, and allowed PJ invasion. Chaining knocked over trees but didn't always kill them. Goodloe spent four years removing chained pinyons and junipers. He observed how fire keeps east African savannas open without taking out all the trees. He thus allows a few elderly trees to remain - those he figures were around before the European invasion. Grass has returned to his ranch-he's now managing to increase species diversity to have grass year-round for cows. Riparian systems are healing, water flowing.

Goodloe is not restoring land to some idealized, earlier state, but he is directing the land towards his idea of a state that sustains natural ecological functions as well as his economic needs. He runs cattle, makes things out of wood, enhances wildlife habitat for hunters who pay to use his property.

Historian Pyne, interviewed for the article and a supporter of Goodloe's efforts, says we can't really go back in time - too much has changed and we wouldn't know which landscapes to choose anyway. Pyne also observes that fire ecology is not a precise lab science. Results are always different-replication is hard to come by.

Moir, W. H. 1982. A fire history of the high Chisos, Big Bend National Park, Texas. Southwestern Naturalist 27:87-98.

Affiliation of author(s): Chihuahuan Desert Research Station

Ecological perspective: This study attempts to determine "natural" fire interval.

Study location, description, and timing: The study took place in the Chisos Mountains, Big Bend, Boot Canyon and Rim. The author looked at fire scars on pinyons that spanned 1770 to 1940 .

Plant species addressed: Study looked at three forest (all Arizona cypress-mix) and one savanna habitat at $6400 \mathrm{ft}$ elevation.

Other context and important points: Cypress and juniper tree ring data are suspect because trees can shut down when it's dry and produce false rings. Pinyons are more reliable.

\section{Results/conclusions relevant to fire management} planning: The 1880s were the watershed time between minor human impact and anglo invasion. The record showed about a 70-year interval between scar-producing fires, and no difference in frequency before and after the 1880s. Sample sizes were quite small ( 7 pines and 3 with multiple scars in canyon habitat; 18 pines and 8 with multiple scars in savanna). The long fire interval leads to big trees. The author says, "Surface fires about every 50 years are one way to maintain the vegetation in some semblance of a natural, fire-regulated condition." 
Mutch, R. W. 1994. A Return to Ecosystem Health. Journal of Forestry (November 1994):31-33.

Affiliation of author(s): Retired USDA Forest Service, Intermountain Research Station turned Missoula forestry consultant

Ecological perspective: "We have failed to sustain the health and productivity of [western forest] ecosystems that have evolved with recurring fires for thousands of years."

Study location, description, and timing: This op-ed piece came out after the 1993 fire season, when over 200,000 acres burned in southern California.

Plant species addressed: Paper talks mainly about ponderosa pine, larch, Douglas-fir forests.

\section{Results/conclusions relevant to fire management} planning: Habitat is not comparable, but paper suggests fire helps in recycling nutrients, regulating plant succession and wildlife habitat, maintaining biological diversity, reducing biomass, and controlling insect and disease populations. The author says that people have understood the necessary role of fire for many decades, but have not been aggressive enough in pursuing restorative prescribed burns. Ultimately the factors that persuade managers to be overcautious about prescribed burning (like threatened and endangered species) end up far worse off after devastating, widespread fires.

Mutch, R. W. 1995. Need for more prescribed fire: but a double standard slows progress. Presented at Environmental Regulation and Prescribed Fire Conference, March 14-17, Missoula, MT.

Affiliation of author(s): Retired USDA Forest Service, Intermountain Research Station turned Missoula forestry consultant

Ecological perspective: Fire is normal in many ecosystems. Despite the evidence that fire suppression has caused terrible problems, politicians and the public are still willing to go all out to support fire suppression efforts. On the other hand, if something goes wrong in a prescribed burn, support is quickly lost.

Plant species addressed: Author uses forest examples.

Other context and important points: At the time of this paper, prescribed burning was generally justified by needs other than maintaining general ecosystem health (reasons included hazard reduction, wildlife habitat improvement, range improvement). The author points out more basic needs for fire (regulating forest age structure, energy cycles, insect populations, plant succession). "Double standard" includes regulatory views that write off wildfire effects (such as air quality, human economic, and endangered species impacts) as extraordinary events but require tight controls for managed burning.

\section{Results/conclusions relevant to fire management} planning: Resource and fire managers need to know the historic frequency, intensity, and size of past fires before developing fire prescriptions.

Neuenschwander, L. F., H. R. Wright, and S. C. Bunting. 1978. The effect of fire on a tobosagrass-mesquite community in the Rolling Plains of Texas. Southwestern Naturalist 23:315-338.

Affiliation of author(s): Forestry, Wildlife and Range, University of Idaho (LFN), Range and Wildlife, Texas Tech (HRW and SCB)

Ecological perspective: The study set out to determine effects of fire on tobosagrass and other species in community from a range management angle.
Study location, description, and timing: The study took place in the Rolling Hills of Texas, Mitchell County, where annual rainfall is $50.3 \mathrm{~cm}$. Areas were sprayed with 2,4,5-T in 1966. Parcels ranging in size from 220 to 1012 ha were burned each year 1970-1974. Sampling was conducted in 1973 and 1974. 
Plant species addressed: Focus is on tobosagrass (Pleuraphis [Hilaria] mutica) and a few shrubs: honey mesquite (Prosopis glandulosa), lotebush (Ziziphus obtusifolia), prickly pear (Opuntia). Data are presented for 121 species.

Other context and important points: It is implied that the spraying was to reduce mesquite. 1973 was a wet year and 1974 was a dry year. In each of these years, plots were sampled and results sorted by number of years since burning. Importance values (IV) were calculated from relative frequency, canopy cover, density, and yield for each species. Controls were not burned, but all but one control plot had been sprayed.

Results/conclusions relevant to fire management planning: Burns of the same age showed higher IV for tobosagrass in the dry year than in the wet year-annuals presumably diluted its IV in the wet year. Forbs were down on burns compared with controls the first season after burning, but increased beyond controls in years 2-4 post-burn. Tobosagrass biomass was 2-4 times higher after burning in the wet year; in dry years it was less than controls. Authors guess tobosagrass equilibrium at 5 years (burns $=$ controls) and subscribe to the removal of litter and annual competitors as the reason for tobosagrass dominance on young burns. Importance value comparisons look at sprayed controls (not the unsprayed control).

IV's for mesquite, lotebush, and prickly pear were also higher in the dry year. Fire killed $55 \%$ of prickly pear, $27 \%$ of mesquite, and no lotebush. Burn plot shrubs did not recover to full control size during the 6 seasons of study; lotebush and prickly pear grew to $70 \%$ or more of sprayed control size in that period. Prickly pear recovery was slow the first two growing seasons, then pads grew rapidly the next three seasons. Mesquite canopy recovered to sprayed control size (less than unsprayed control size) by the $6^{\text {th }}$ season post-burn.

The effects of spraying (aerial application, so all the plants got it) are not really sorted out or discussed with the exception of speculation that "Spraying followed by burning may reduce the sphere of influence of honey mesquite for about 20 years."

Peacock, G. L. 1981. Flammability-internal water status of shrubs. P. 62-101 in G. M. Ahlstrand, principal investigator. Ecology of fire in the Guadalupe Mountains and adjacent Chihuahuan Desert. Carlsbad Caverns and Guadalupe Mountains National Parks, Carlsbad, NM.

Affiliation of author(s): Graduate student at Texas Tech (masters thesis excerpt)

Ecological perspective: Study views reintroduction of fire necessary to shift shrublands back to grasslands. Information about plant water status is important for determining burn prescriptions.

Study location, description, and timing: Pine Spring Canyon, elevation 1775 m, Guadalupe Mountains National Park. Study timing is not stated. The document presents precipitation and temperature data for 19771979 , and the publication is dated 1981, so late 1970s is a guess. Season is also not stated. Intent of study is to provide predictive equations through multiple regression for fire intensity (degree of consumption of samples) as a function of leaf water content, xylem sap tension, relative humidity, air temperature, number of days since precipitation $\geq .635 \mathrm{~cm}$, and number of days since precipitation $\geq 2.54 \mathrm{~cm}$.

Plant species addressed: Quercus grisea, Cercocarpus montanus, Fallugia paradoxa. Habitat called "open woodland-grassland" by Northington and Burgess (1979) and "canyon-chaparral" by Warnock (no date).

\section{Results/conclusions relevant to fire management} planning: Correlation coefficients were unexpectedly low between leaf water content and flammability and between xylem sap tension and flammability. The author suggests his technique rather than a real lack of relationship might be responsible. However, "other factors such as crude fat, resins, waxes, and oils may assume a greater importance in determining flammability." Best fit equations for each species combined leaf water content, xylem sap tension, relative humidity, air temperature and number of days since precipitation $\geq .635 \mathrm{~cm}$ and $\geq 2.54 \mathrm{~cm}$. Wind speed was discarded "because of the low range of values obtained during sampling."

For all three species, air temperatures were the most important predictors of flammability. "At temperatures below $15^{\circ} \mathrm{C}$, the flammability of each species was low, and the possibility of a fire carrying through the crown of each species would be small. Flammability was high, and fires would be very intense at temperatures above $28^{\circ} \mathrm{C}$. The objectives of most prescribed burns could be achieved by conducting burns at temperatures between $15^{\circ} \mathrm{C}$ and $25^{\circ} \mathrm{C}$ when the fire would be of a moderate intensity and easily controlled." 
Russell, K. R., D. H. Van Lear, and D. C. Guynn, Jr. 1999. Prescribed fire effects on herpetofauna. Wildlife Society Bulletin 27:374-384.

Affiliation of author(s): Department of Forest Resources, Clemson University

Ecological perspective: Prescribed burning is used to achieve many objectives, but responses of reptiles and amphibians have received little attention.

Study location, description, and timing: Review paper covering wide range of geography and habitats. It considers both direct effects of fire on animals and indirect habitat responses.

Other context and important points: It is important to know more in light of the general amphibian decline.

\section{Results/conclusions relevant to fire management planning:}

Direct effects:

- The literature reports both "calm" and "panicked" responses of herps as fire approaches.

- Wet areas may provide refugia for amphibians.

- Sceloporus occidentalis in California chaparral take cover under surface objects, colonize burned areas, and use burned branches for perching.

- Eastern box and mud turtles burrow into soil.

- Many herps use the burrows of other animals for shelter from fire.

- Lizards and large snakes (mobile herps) may simply disperse from burning areas.

- Very low mortality was observed in eastern diamondbacks after a prescribed burn in Florida, and the 2 (of 68) killed snakes were in the middle of shedding.

- Eastern glass lizards incur significant direct mortality, but given that the lizard's distribution is largely southeastern Coastal Plain, where fire and other disturbances are common, the authors suspect short-term mortality is offset by benefits of fire in maintaining the species' grassland and pine flatwood habitat.

- An Australian study found no lizard deaths from early dry-season fires, but $29 \%$ mortality from late dryseason fires, attributed to higher intensity of fire and lizard seasonal habitat shifts.

- Quoting an earlier review, 'it is illogical that animals associated with fire vegetation are not themselves at least behaviorally adapted to resist mortality by fire.'

Habitat effects:

- Richness of arboreal and terrestrial reptiles was lower in California chaparral areas either converted to grasslands by very frequent (even annual) fires or allowed to succeed to very dense stands in the absence of fire.
- Literature reporting studies from a number of places in the world (African savannas, "fire-prone ecosystems" in Australia and New Zealand, xeric Florida pine forests) states that natural and prescribed burns increase herp diversity in habitats where fire was historically present despite population declines for some species immediately after fires.

- Herp community in Florida longleaf/shortleaf pine stand that experienced annual burning shifted to all different species in stands that weren't burned and had succeeded to a closed-canopy beech-magnolia association.

- Fire suppression is implicated in the threatened listing of the gopher tortoise over parts of its range - the tortoise needs open habitat. The loss of the tortoise affects many species that use gopher tortoise burrows for nesting, feeding or cover (one review cites 332 species using burrows).

- Prescribed fire benefits accrue if burning takes place during the appropriate season.

- Negative impacts of burning are likely greatest for leaf litter species.

- Fire is also needed to maintain wetland habitats.

"Without fire, accumulation of organic matter creates substrate conditions that allow succession of many isolated wetlands to shrub thickets and eventually closedcanopy hardwood stands." Well-meaning "protective" firebreaks around wetlands make the problem worse.

- Using herbicides as a substitute for prescribed fire is not recommended until there are studies available that document their effectiveness in mimicking the impact of fire on landscapes and their safety for amphibians and reptiles.

"Prescribed fire is indicated as an appropriate management tool that can be used with other treatments to benefit herpetofauna by restoring a historical mosaic of successional stages, habitat structures, and plant species compositions"

“....caution must be exercised when extending conclusions to other regions where fire was a less frequent or intensive historical disturbance regime."

"Even in fire-dependent ecosystems of the southeastern United States, where most studies indicate positive relationships between herpetofauna and prescribed burning, a lack of rigorous experimental design (e.g., small sample sizes, single or no controls, no treatment replication) in several studies ultimately may limit conclusions concerning these relationships." 
Schott, M. R., and R. D. Pieper. 1987. Succession of pinyon-juniper communities after mechanical disturbance in southcentral New Mexico. Journal of Range Management 40: 88-94.

Affiliation of author(s): Oregon State research associate (MRS) and animal/range science professor New Mexico State University (RDP).

Ecological perspective: The study is a long-term look at recovery from cabling or bulldozing of pinyons and junipers.

Study location, description, and timing: Authors selected previously treated sites in the Sacramento Mountains, NM to sample in 1982 and 1983, controlling as best as they could for soil uniformity, aspect, slope, and elevation. Sites selected were cabled or bulldozed in 1950, 1954, or 1975 (or not at all). 15 x $25 \mathrm{~m}$ plots were located parallel with slope on each site, and two $25-\mathrm{m}$ transects run in the plots to measure canopy cover by species. Principle component analysis was conducted on cover estimates that looked at soil depth, aspect, elevation, slope, \% rockiness, bare ground, litter cover, type of disturbance, severity of disturbance.

Plant species addressed: Pinus edulis, Juniperus monosperma, J. deppeana, Lycurus phleoides, Muhlenbergia dubia, M. repens, Bouteloua curtipendula, B. gracilis, Gutierrezia sarothrae, Eriogonum heiracifolium, Quercus undulata.
Results/conclusions relevant to fire management planning: Given the number of factors considered in the analysis, the individual findings are numerous (but not presented in tables in the paper). From the abstract:

"Grasses on the deeper soils usually increased after cabling, but after 25 years they had declined to near pretreatment levels. ["Pretreatment" levels weren't determined, so this term must refer to data collected from plots that hadn't been cabled or bulldozed.] Wavyleaf oak (Q. undulata) increased after cabling, and on the older cablings it had reached higher cover values than on the other community types. Pinyon and juniper response appeared to be dependent on density and size of trees before cabling. If the stand was near climax before cabling, pinyons rapidly became dominant on the site. If it was seral, there would be more junipers, but their slow growth and the time they require for maturation required more time before they dominated the site. The successional pattern following cabling on relatively deep soils is similar to what was found after fire, but it occurs faster. Cover of grasses and shrubs increased more on rock-free soils compared to sites treated similarly but with rock. The ordinations indicated that succession in pinyonjuniper communities is directional and leads towards climax with a decrease in variability among sites."

Severson, K. E., 1986. Small mammals in modified pinyon-juniper woodlands, New Mexico. Journal of Range Management 39:31-34.

Affiliation of author(s): USDA Forest Service research wildlife biologist, Arizona State University

Ecological perspective: This work tests the hypothesis that rodents are unaffected by pinyon-juniper (PJ) "treatments." The study also intended to add data from ungrazed areas (no livestock but plenty of deer and elk) to the PJ treatment-recovery literature.

Study location, description, and timing: Three-year (1981-1983) study looked at rodent species and numbers in PJ woodlands (1880-2024 m elevation) in the Gila NF near Silver City. PJ treatments included two, (one higher elevation and one lower) 120-ha plots each of: bulldozed, bulldozed-piled-burned, thinned, and untreated. The bulldozing and thinning treatments pushed over all trees but left remains in place. Trapping took place mid-
September each year in half the paired plots (half the plots were sampled twice, other half once). Traps were set for 4 consecutive days on transects through plots.

Plant species addressed: Pinus edulis, Juniperus monosperma, and $J$. deppeana. Other prominent species in the area included Quercus grisea, Cercocarpus breviflorus, Bouteloua gracilis and B. curtipendula.

Other context and important points: Treatment took place 13 or 18 years prior to study; no livestock grazing since that time. Average annual precipitation $=393 \mathrm{~mm}$ (55\% falling in summer); average temperature $=12.8^{\circ} \mathrm{C}$.

Results/conclusions relevant to fire management planning: Pinyons had been reestablishing faster than junipers on plots; broad-leaved shrub densities were 
higher under "well-developed tree overstories." PJ densities were lowest on bulldozed and bulldozed-piledburned treatments. There was two to three times as much slash on thinned and on bulldozed plots than on untreated.

Ten rodent species were found on all treatments, with 13 total. Significantly higher numbers of individuals were found on untreated tracts, with no differences among the various removal treatments. The only elevation effects observed were more abundant woodrats on lower plots (1880-1935 m) and more brush mice on higher plots (1935-2040 m). Other significant results:
- Greater numbers of woodrats on bulldozed and thinned (liked slash piles)

- Greater numbers of brush mice on bulldozed and thinned (liked slash piles)

- Greater numbers of pinyon \& rock mice on thinned; lowest on 2 bulldozed treatments (preferred overstory)

- Greater numbers of grassland rodents higher on bulldozed-piled-burned; lower where overstory remained.

The study showed there are management options relative to particular rodent species.

Severson, K. E., 1986. Woody plants reestablishment in modified pinyon-juniper woodlands, New Mexico. Journal of Range Management 39:438-442.

\begin{abstract}
Affiliation of author(s): USDA Forest Service research wildlife biologist, Arizona State University
\end{abstract}

Ecological perspective: Looking at regrowth in treated P$\mathrm{J}$ habitats that had experienced heavy livestock grazing between 1869 and 1937, light to moderate grazing between 1937 and 1967, and little to no grazing since that time.

Study location, description, and timing: P-J woodlands (1880-2024 m elevation) in the Gila NF near Silver City. P-J treatments 13 and 18 years prior to study (in 1965 and 1970) included two (1 higher elevation and 1 lower) 120-ha plots each of: bulldozed, bulldozed-piled-burned, thinned, and untreated. The bulldozing and thinning treatments pushed over all trees but left remains in place. Shrub and tree density was determined by counting individuals on $5 \times 35 \mathrm{~m}$ random plots; heights were also measured. Pinyons on a 5-m-wide belt transect on the big plots were cut and dated by the UA tree ring lab.

Plant species addressed: Pinus edulis, Juniperus monosperma, and $J$. deppeana. Other prominent species in the area included Quercus grisea, Cercocarpus breviflorus, Bouteloua gracilis and B. curtipendula.

Other context and important points: Treatment took place 13 or 18 years prior to study; no livestock grazing since that time. Average annual precipitation $=393 \mathrm{~mm}$ (55\% falling in summer); average temperature $=12.8^{\circ} \mathrm{C}$.
Results/conclusions relevant to fire management planning: Densities of total $\mathrm{P}$ and $\mathrm{J}$ and $\mathrm{J}$ only were significantly lower on bulldozed and left or bulldozedpiled-burned versus untreated and thinned plots; densities or heights were not significantly different between either treatment in the two groups (untreated and thinned or bulldozed/left and bulldozed-piled-burned/left). Species responded differently:

- One-seed juniper and pinyon were more abundant on thinned than on untreated

- Alligator juniper was more abundant on bulldozed than on thinned

- One-seed juniper and pinyon reinvaded treated areas faster than alligator juniper

- Pinyons were more abundant in the younger treatments (1970), but those plots were also located at higher elevation.

Greater abundance of one-seed juniper and pinyon on thinned plots might be explained by better conditions for seedlings in terms of reduced competition for moisture. All 3 species were taller on untreated and thinned plots than on either bulldozed treatment. Tree ring and census data showed pinyons began increasing rapidly on untreated plots after the mid-1960s. The other (non-P and J) shrub species were more numerous on untreated plots. "None of the pinyon-juniper treatments resulted in increased browse plant establishment or height growth. 
Swetnam, T. W., C. D. Allen, and J. L. Betancourt. 1999. Applied historical ecology: using the past to manage for the future. Ecological Applications 9:1189-1206.

Affiliation of author(s): TWS-University of Arizona laboratory of tree ring research, CDA-USGS Jemez Mountains Field Station, JLB-USGS Desert Laboratory

Ecological perspective: Understanding historical trends is important but doesn't necessarily make management decisions easier.

Study location, description, and timing: This paper is a review article, but it focuses on the Southwest.

\section{Results/conclusions relevant to fire management planning:}

- Archival records are natural (sediments, tree rings) or documentary (human records). National Geophysical DataCenter, NOAA, Boulder is a worldwide databank for documentary records - data are available on the web.

- Historical reconstructions are improved by combining natural and documentary records.

- Inherent limitations of reconstructions include how records hold up over time, specialized locations of natural records, bias in human documentation of phenomena, and assumptions that processes creating records are continuing unchanged today.

- The validity of extrapolating reference conditions from a site likely decreases as a function of distance in time and space from the site of interest.

- Historical research shows that some current species "invasions" might not necessarily be results of recent human alteration of the landscape. Increases in pinyon pines in Chaco Canyon today may be recovery from Anasazi overharvesting 1000 years ago. Pinyon range extensions in Northern Colorado are likely a climaterelated migration, though in future years they could be (mis)interpreted as responses to urbanization on the front range.

- Fire scar-based fire histories have limitations (the main one being that only certain trees and shrubs record fire events), but their application has confirmed the modern reduction in forest fire frequency. Without the historical record, it would have been difficult to justify abandoning fire suppression practices that have produced unhealthy forests.

- Repeat photography from the air or space can reveal broad-scale landscape changes while avoiding biases of the process on the local scale-when historical photographs of individual scenes are used, it is impossible to know if the shots were representative of broader patterns. Aerial photos showed the invasion of conifers into the ancient grassland at Cerro Grande (that was judged to be due to grazing and fire suppression). - Rather than using history to make direct predictions, it should be applied to know the natural range of conditions present in a place. The possibility of nonequilibrium should be acknowledged, as should the subjectivity of judgments of what is "natural."

Vogl, R. J. 1974. Effects of fire on grasslands. P. 139-194 in T. T. Kozlowski and C. E. Ahlgren editors. Fire and Ecosystems. Academic Press, New York.

Ecological perspective: This paper is a broad review that considers grassland origins first and the role of fire second ("in order to have a prairie fire there must first be a prairie").

Other context and important points: (Just an interesting theory-fires can occur while plants are in flower, and the heat may promote mutations in gametes that help give rise to the variety seen in some groups of grasses.)

\section{Results/conclusions relevant to fire management planning: \\ - The author delineates anthropogenic, derived} (successional), and true (natural climax) grasslands. There is agreement that fire is usually important in maintaining the first two types, but not the third. Climate and soil are of primary importance to "true" grasslands, then other factors, including fire, come next as maintenance and renewal agents.

- Important causes of grassland fires have been man, lightning, spontaneous combustion, sparks from falling rock, volcanic eruptions.

- Oft-cited "driving game" motive for humans lighting grasslands is questioned because many grassland animals are not fearful of fire.

- A little lightning could go a long way on the uninterrupted grasslands of the past, and firestorm systems were able to produce violent rainstorms (a feat replicated on purpose by grassland-dwelling humans). Overgrazing, mowing, and plowing have significantly curtailed the spread of modern lightning fires.

- Early accounts accepted grassland fires as normal, and some acknowledged ecological roles. 
- "Grassland climates facilitate fires by the occurrence of dormant periods, dry seasons, and periodic droughts."

- Grassland plants die back annually thus burn readily. Grassland conditions are not conducive to rapid decomposition, thus plant debris accumulates and adds to the fuel load.

- "Grasslands with optimum growing conditions are more consistently stimulated by fire than those occupying marginal sites, particularly areas with critical moisture conditions."

- Erosion is not usually a post-fire problem because grasslands commonly occupy level sites. It is most evident where bunch grasses grow on steep slopes in regions receiving heavy rains.

- "The presence of recurring disturbances such as fires favors grasslands ... in regions with climates capable of supporting brush or forest. . . . If an area is subject to high fire frequencies, the chances of it being occupied by grassland as opposed to brushland, chaparral, or forest are influenced by burning times, fire intensities, climate, soils, biotic factors. . . . With few exceptions, fire-adapted woody species that can withstand fire or recover from it cannot continue to survive in large numbers in grassland areas that support intense fires on a very frequent, annual, or repeated basis.

- Burning doesn't necessarily favor perennials over annuals unless annuals are caught as they begin to grow.

"The time of burning and the frequencies of fire can be so critical in some grasslands that the results can either be beneficial or detrimental."

Variable results of fire reported in the literature can be explained by research biases but more frequently by the fact that no two fires, or the conditions under which they occur, are alike.

White, L. D. 1969. Effects of a wildfire on several desert grassland shrub species. Journal of Range Management 22:284-285.

\section{Affiliation of author(s): University of Arizona}

Ecological perspective: Brush control on the range is the focus of this paper.

Study location, description, and timing: Fifty plants of each species (below) were randomly selected and classified (light, moderate, severe) for fire damage after a June 1963 wildfire near Sasabe, AZ.

Plant species addressed: false mesquite (Calliandra eriophylla), turpentine bush (Ericameria [Aplopappus] laricifolia), velvet mesquite (Prosopis velutina [juliflora]), ocotillo (Fouquieria splendens), velvetpod mimosa (Mimosa dysocarpa), sotol (Dasylirion wheeleri)

Other context and important points: "Recent studies indicate that grazing and lack of range fires are both important causes of the [shrub] invasion."

\section{Results/conclusions relevant to fire management planning:}

- Moderately and lightly burned Calliandra survived 2 seasons at significantly higher rates than severely damaged plants.

- Ericameria showed higher damage than other species.

- Prosopis sprouting was significantly different between light and moderate or severe damage. Severely burned plants produced only basal sprouts; $20 \%$ of lightmoderately burned plants produced basal sprouts and refoliation.

- Fouquieria survival varied among three damage classes the first year, but was only significantly lower in severe class the second year.

- Mimosa survival was high for all classes but lowest in severe the first year. No differences were observed the second year.

- Moderately and lightly burned Dasylirion survived the fire; only $3 \%$ of severely damaged plants survived. No basal sprouting was observed; refoliation from terminal bud was deemed to equal recovery. 
Wright, H. A. 1990. Role of fire in the management of Southwestern ecosystems. P. 1-5 in J. S. Krammes, technical coordinator. Effects of Fire Management of Southwestern Natural Resources. General Technical Report RM-191. USDA Forest Service, Rocky Mountain Forest and Range Experiment Station. Fort Collins, CO. 293 p.

Affiliation of author(s): Texas Tech Range and Wildlife Department

Ecological perspective: There is no single role of fire across Southwestern ecosystems, though fire was historically present in most systems.

Study location, description, and timing: This paper is an end-of-career overview of fire in Southwestern U.S. systems.

Other context and important points: "Fire is not a cureall for our management problems. However it is effective and cheap for many land management problems if used by people skilled in the use of prescribed fire."

\section{Results/conclusions relevant to fire management planning:}

- Role of fire in semidesert grass-shrub community is somewhat "perplexing." Historical photos from Santa Rita Experimental Range shows shrub-free communities where mesquite dominates today. The change is probably not explained simply by a lack of fire, but by a combination of drought, competition, herbivores, and lack of fire. Wide swings in grass production are natural, but adding grazing puts too much stress on grasses and favors shrubs, especially under drought conditions. Using fire to control shrubs in this system when it is under high stress may further damage grasses rather than favor them. "....poor rangelands cannot be restored with fire." Burning should take place in June only after two years of better than average plant growth.

- Arizona chaparral has a lower fire frequency than California chaparral and is thought to be a climax vegetation state. "In general, fire helps to keep chaparral communities diverse and productive if fires do not occur more frequently than 20 to 30 years." Fire maintains species diversity, and many species are vigorous resprouters (shrub live oak, sugar sumac, skunkbush sumac, Wright silktassel, redberry, catclaw mimosa, Emory oak, yerbasanta, mountain mahoganies). Other species germinate from seed after fires. Grasses and forbs are plentiful through the fourth year after fire then disappear,

- Fire frequency in the oak brush zone is speculated to be 50 to 100 years. Spotty, irregular fires occur after leaf litter builds up.

- Fire has historically controlled the distribution of pinyon-juniper, particularly juniper, "but fire cannot be separated from the effects of drought and competition." The three factors probably worked together before grazing. Fires every 10-30 years kept juniper on shallow, rocky, rough places. Reduced competition from grasses due to grazing has allowed trees to invade, although some pinyon pine "invasions" may actually be reestablishments. Prescribed burning to control must be under very hot, dry, and windy conditions to succeed; mechanical treatment followed by burning 2-3 years later is definitely safer, though more expensive. Reburning of PJ stands converted to grass at tree height of 4 feet is recommended or about every 20 to 40 years.

Fires probably occurred in shrub-grasslands in Texas (southern Great Plains) every 5 to 10 years, most often following droughts after one to three years of above average moisture. "Fires suppress shrub growth and provide herbaceous competition for new shrub seedlings. Moreover, rodents and lagomophs feed on the young seedlings and resprouts...."

York, J. C. and W. A. Dick-Peddie. 1969. Vegetation changes in southern New Mexico during the past hundred years. P. 157-166 in W. G. McGinnies and B. J. Goldman, editors. Arid Lands in Perspective. University of Arizona Press, Tucson. 421 p.

Affiliation of author(s): New Mexico State University Biology Department

Ecological perspective: 1) "Was southern New Mexico a grassland prior to extreme human disturbance? 2) Is the vegetation of southern New Mexico in a successional stage, a disclimax, or a climax condition at the present time?"

Study location, description, and timing: The authors created a "transect" across southern New Mexico with vegetation notes from survey records from the period between 1858 and 1904, then they made qualitative observations of modern vegetation for comparison.

Plant species addressed: Juniperus spp., Atriplex canescens, Larrea tridentata, Acacia greggii, Acacia constricta, Chilopsis linearis, Yucca elata, Fallugia paradoxa.

Results/conclusions relevant to fire management planning: The authors observed that most of the 
previously grassy areas (mostly Bouteloua spp.) were shrublands at the time of their survey. Because of the speed of change and because some areas protected from grazing had remained unchanged, they concluded that climate change was not involved in the grass-to-shrub shift elsewhere. They believe fire played little part in determining present patterns - erratic topography and lower litter accumulation in black grama grasslands make it doubtful that the area could carry widespread fire. Specific observations from the earlier surveys included: - "Mesquite occurred in limited areas on shallow sandy soils...." It also occurred around Indian campsites, and the authors suspect that Indian use of mesquite seeded these pockets which became centers of distribution when hordes of cattle appeared on the scene (and also helped distribute the plant).
- "Creosotebush (Larrea) was restricted to welldrained gravelly hilltops and narrow patches in the foothills of mountains."

- "Juniper stands were on mountain foothills usually higher or further north than creosotebush."

"Today the mesas and rolling hills of southern New Mexico are dominated by creosotebush, tarbush, and mesquite. There are many tobosa swales, and occasionally large stands of yucca occur in swales and on the surrounding mesas. Juniper stands often meet and merge with the desert shrubs. In almost all cases, grama grass is merely a subdominant, if it is present at all."

And the authors' answers to the questions under "Ecological perspective" are: (1) yes, it used to be a grassland, and (2) it's now a desert climax. 
Appendix 2. Summary of fire effects on Gelbach's (1967) leading dominant plant species of the Guadalupe Escarpment. Plants are listed in order of importance in Gelbach's physiognomic scheme. Information is gleaned from USDA Forest Service Fire Effects Information System (www.fs.fed.us/database/feis) and Ahlstrand's (1981b) review. Scientific names have been updated according to the USDA NRCS Plants Database (http://plants.usda.gov). Review sources: FEIS=Fire Effects Information System; A=Ahlstrand; see sources for original citations.

\begin{tabular}{|c|c|c|c|c|}
\hline Species & Common Name & Response to Fire & FEIS & A \\
\hline Agave lechuguilla & lechuguilla & $\begin{array}{l}\text { reproduces vegetatively, sometimes after several seasons, } \\
\text { if less than half of leaves scorched; usually dies if more } \\
\text { than half scorched; high temperatures depress } \\
\text { germination rates; month of burning and available soil } \\
\text { moisture affect rate of recovery }\end{array}$ & $\mathrm{x}$ & $\mathrm{x}$ \\
\hline Quercus grisea & gray oak & $\begin{array}{l}\text { no studies directly on gray oak, but can infer from } \\
\text { conclusion that all "Arizona" oaks sprout prolifically } \\
\text { following topkill by fire, that gray oak would too }\end{array}$ & $\mathrm{x}$ & \\
\hline $\begin{array}{l}\text { Juniperus } \\
\text { monospema }\end{array}$ & oneseed juniper & $\begin{array}{l}\text { trees under } 4 \text { feet killed by spring fire; heat damage } \\
\text { could take } 1-2 \text { years to appear }\end{array}$ & $\mathrm{x}$ & $\mathrm{x}$ \\
\hline $\begin{array}{l}\text { Dasylirion } \\
\text { leiophyllum }\end{array}$ & sotol & $\begin{array}{l}\text { fire decreases coverage and frequency significantly; some } \\
\text { sprouting from terminal buds; flowering staks attract } \\
\text { lightning and plant tops can spread fire when they detach } \\
\text { from stems and roll }\end{array}$ & $\mathrm{x}$ & $\mathrm{x}$ \\
\hline Larrea tridentata & creosotebush & $\begin{array}{l}\text { creosote can resprout after very low intensity fires, but is } \\
\text { frequently killed by fire; normal habitat cannot effectively } \\
\text { carry fire; drier than normal conditions increase mortality } \\
\text { from fire }\end{array}$ & $\mathrm{x}$ & $\mathrm{x}$ \\
\hline Acacia constricta & whitethorn acacia & fire topkills, but plants resprout & $\mathrm{x}$ & \\
\hline Mimosa biuncifera & catclaw mimosa & $\begin{array}{l}\text { coverage initially reduced, then sprouts profusely; full } \\
\text { recovery within } 5 \text { years }\end{array}$ & $\mathrm{x}$ & $\mathrm{x}$ \\
\hline $\begin{array}{l}\text { Juniperus } \\
\text { deppeana }\end{array}$ & alligator juniper & $\begin{array}{l}\text { canopy usually high enough to avoid flames; sprouts from } \\
\text { base; young trees more susceptible; burning checked } \\
\text { "invasion" in ponderosa pine }\end{array}$ & $\mathrm{x}$ & $\mathrm{x}$ \\
\hline
\end{tabular}




\section{Appendix 2, continued. Summary of Fire Effects on Gelbach's (1967) Leading Dominant Plant Species of the Guadalupe Escarpment.}

\begin{tabular}{|c|c|c|c|c|}
\hline Species & Common Name & Response to Fire & FEIS & A \\
\hline Opuntia imbricata & tree cholla & $\begin{array}{l}\text { initially thinned by fire ( } 50 \% \text { mortality observed }) \text { but } \\
\text { reported to recover to greater than preburn density after } \\
13 \text { years; small plants more susceptible; mortality is } \\
\text { increased by surrounding vegetation that generates higher } \\
\text { fire temperatures; other damage observed postfire-more } \\
\text { insect, mammal, and drought effects }\end{array}$ & & $\mathrm{x}$ \\
\hline Viguiera stenoloba & resin bush & $\begin{array}{l}\text { topkilled but resprouts; higher frequencies on burned } \\
\text { sites }\end{array}$ & $\mathrm{x}$ & $\mathrm{x}$ \\
\hline $\begin{array}{l}\text { Muhlenbergia } \\
\text { setifolia }\end{array}$ & curly leaf muhly & $\begin{array}{l}\text { no difference in coverage and frequency between burned } \\
\text { and unburned sites after } 3 \text { years }\end{array}$ & & $\mathrm{x}$ \\
\hline Flourensia cernua & tarbush & $\begin{array}{l}\text { no studies, but plant occurs in habitats where fire is rare; } \\
\text { fire likely kills it and recovery would be via seeds }\end{array}$ & $\mathrm{x}$ & $\mathrm{x}$ \\
\hline $\begin{array}{l}\text { Opuntia } \\
\text { phaecantha }\end{array}$ & prickly pear & $\begin{array}{l}32 \% \text { to } 50 \% \text { mortality reported but cool fire had little } \\
\text { effect }\end{array}$ & & $\mathrm{x}$ \\
\hline $\begin{array}{l}\text { Bouteloua } \\
\text { eriopoda }\end{array}$ & black grama & $\begin{array}{l}\text { appears to be initially set back by most fires but } \\
\text { increases over the long term; post-fire drought and } \\
\text { grazing lengthens recovery; poor seed production and } \\
\text { expansion via stolons and layering argue for historically } \\
\text { infrequent fires where the grass dominates }\end{array}$ & $\mathrm{x}$ & $\mathrm{x}$ \\
\hline B. hirsuta & hairy grama & $\begin{array}{l}40 \% \text { loss in basal cover reported } 1 \text { year after burn, but } \\
\text { most studies show no damage after a season or two } \\
\text { reduced production }\end{array}$ & $\mathrm{x}$ & $\mathrm{x}$ \\
\hline B. curtipendula & sideoats grama & $\begin{array}{l}\text { top growth killed; production } 50 \% \text { less on burned than } \\
\text { unburned areas after dry-year March burn but most } \\
\text { studies report burning has little or no effect; rhizomatous } \\
\text { form (var. curtipendula) harmed by fire in dry years but } \\
\text { not wet; bunchgrass form (var. caespitosa) "thrives" on } \\
\text { fire }\end{array}$ & $\mathrm{x}$ & $\mathrm{x}$ \\
\hline $\begin{array}{l}\text { Juglans } \\
\text { microcarpa }\end{array}$ & little walnut & $\begin{array}{l}\text { riparian species with few adaptations to fire exhibited; } \\
\text { reestablishment presumed via seeds but closely related } \\
\text { black walnut sprouts from stump after fire }\end{array}$ & $\mathrm{x}$ & \\
\hline $\begin{array}{l}\text { Acer } \\
\text { grandidentatum }\end{array}$ & bigtooth maple & $\begin{array}{l}\text { stands burn infrequently; plants killed or topkilled; some } \\
\text { resprouting but vigor thought to be low }\end{array}$ & $\mathrm{x}$ & \\
\hline Nolina microcarpa & sacahuista & $\begin{array}{l}\text { sprouts from woody, underground caudex after cool to } \\
\text { moderate fires; moderate to hot fires kill significant } \\
\text { numbers of mature plants and most young ones }\end{array}$ & $\mathrm{x}$ & \\
\hline Aristida purpurea & purple threeawn & $\begin{array}{l}\text { generally reduced by fire for several growing seasons; } \\
\text { rootcrowns are close to surface and easily damaged by } \\
\text { fire burning in accumulated litter }\end{array}$ & $\mathrm{x}$ & \\
\hline
\end{tabular}


